Article

\title{
Herb-Drug Interaction of Red Ginseng Extract and Ginsenoside Rc with Valsartan in Rats
}

\author{
Ji-Hyeon Jeon ${ }^{1}$, Sowon Lee ${ }^{1}$, Wonpyo Lee ${ }^{2}$, Sojeong Jin ${ }^{2}$, Mihwa Kwon ${ }^{1}$, Chul Hwi Shin ${ }^{1}$, \\ Min-Koo Choi ${ }^{2, *}$ and Im-Sook Song ${ }^{1, *}$ (D) \\ 1 College of Pharmacy and Research Institute of Pharmaceutical Sciences, Kyungpook National University, \\ Daegu 41566, Korea; kei7016@naver.com (J.-H.J.); okjin917@hanmail.net (S.L.); mihwa_k@naver.com (M.K.); \\ tusshinn@gmail.com (C.H.S.) \\ 2 College of Pharmacy, Dankook University, Cheon-an 31116, Korea; woopyo906@gmail.com (W.L.); \\ astraea327@naver.com (S.J.) \\ * Correspondence: minkoochoi@dankook.ac.kr (M.-K.C.); isssong@knu.ac.kr (I.-S.S.); Tel.: +82-41-550-1432 \\ (M.-K.C.); +82-53-950-8575 (I.-S.S.)
}

Received: 14 November 2019; Accepted: 29 January 2020; Published: 31 January 2020

\begin{abstract}
The purpose of this study was to investigate the herb-drug interactions involving red ginseng extract (RGE) or ginsenoside Rc with valsartan, a substrate for organic anion transporting polypeptide (OATP/Oatp) transporters. In HEK293 cells overexpressing drug transporters, the protopanaxadiol (PPD)-type ginsenosides- Rb1, Rb2, Rc, Rd, Rg3, compound K, and Rh2-inhibited human OATP1B1 and OATP1B3 transporters ( $\mathrm{IC}_{50}$ values of 7.99-68.2 $\mu \mathrm{M}$ for OATP1B1; 1.36-30.8 $\mu \mathrm{M}$ for OATP1B3), suggesting the herb-drug interaction of PPD-type ginsenosides involving OATPs. Protopanaxatriol (PPT)-type ginsenosides-Re, Rg1, and Rh1-did not inhibit OATP1B1 and OATP1B3 and all ginsenosides tested didn't inhibit OCT and OAT transporters. However, in rats, neither RGE nor Rc, a potent OATP inhibitor among PPD-type ginsenoside, changed in vivo pharmacokinetics of valsartan following repeated oral administration of RGE $(1.5 \mathrm{~g} / \mathrm{kg} /$ day for 7 days) or repeated intravenous injection of Rc ( $3 \mathrm{mg} / \mathrm{kg}$ for 5 days). The lack of in vivo herb-drug interaction between orally administered RGE and valsartan could be attributed to the low plasma concentration of PPD-type ginsenosides (5.3-48.4 nM). Even high plasma concentration of Rc did not effectively alter the pharmacokinetics of valsartan because of high protein binding and the limited liver distribution of Rc. The results, in conclusion, would provide useful information for herb-drug interaction between RGE or PPD-type ginsenosides and Oatp substrate drugs.
\end{abstract}

Keywords: red ginseng extract (RGE); ginsenoside Rc; herb-drug interaction; organic anion transporting polypeptide (Oatp); valsartan

\section{Introduction}

Ginseng is one of the most popular plants in Asia, Europe, and USA [1,2] owing to its vitality restoration and immunostimulating effect [1]. The therapeutic benefits of ginseng include anti-diabetic and anti-inflammatory effect and anti-oxidative response on chronic liver disease [3-8]. Ginseng is also commonly used due to its potential as a chemo-preventive agent and adjuvant therapy [9]. These pharmacological activities have also been observed for various ginsenosides mainly present in ginseng products [4].

Due to the growing use of herbal medicine and convenience of taking herbal formulations, herb-drug interactions caused by the co-administration of herbal medicine with therapeutic drugs have also rapidly increased from $13.8 \%$ in 2010 to $17.3 \%$ in 2013 among adverse drug reactions in China [10]. 
The most frequently reported cases of herb-drug interactions include the modulation of drug metabolizing enzymes and transporters by herbal medicines and the causative pharmacokinetic alterations of co-administered therapeutic drugs that may acts as substrates for drug metabolizing enzymes and transporters $[8,11]$. In case of ginseng interactions, it was reported that no herb-drug interaction between single oral dose of Korean red ginseng extract (RGE) $(0.5-2.0 \mathrm{~g} / \mathrm{kg}$ ) and the probe substrates for five cytochrome P450 (CYP) enzymes (i.e., CYP1A2, 2C9, 2C19, 2D6, 3A) in mouse [12]. Repeated oral administration of RGE $(0.5 \mathrm{~g} / \mathrm{kg}$ for 2 weeks in mice and $85 \mathrm{mg}$ total ginsenosides for 2 weeks in human) did not alter the metabolic activity of above 5 CYP enzymes in the mouse liver [13] and could not induce clinically significant interaction in human [14,15]. In a study conducted by Malati et al. [16], Korean ginseng ( $0.5 \mathrm{~g}$ capsule twice daily for 28 days) induced CYP3A activity and decrease plasma concentration of midazolam following oral administration of $8 \mathrm{mg}$ midazolam. The expression levels of organic anion transporter 1 (Oat1) and Oat 3 in the kidney and P-glycoprotein $(\mathrm{P}-\mathrm{gp})$ in the liver were increased by the repeated administration of RGE (30-300 mg/kg for 2 weeks) in mice, which were accompanied with the dose dependent decrease in the area under the plasma concentration-time curve (AUC) of fexofenadine, a substrate for P-gp [17]. In another study using rats, the bioavailability of fexofenadine was decreased by $16.1 \%$ following repeated administration of ginseng radix extract $(150 \mathrm{mg} / \mathrm{kg} /$ day for 2 weeks), which may be explained by reduced absorption of fexofenadine due to the induction of intestinal P-gp [18]. Repeated RGE treatment was reported to decrease multidrug resistance-related protein 2 (Mrp2) mRNA and protein expression, consequently decreasing the biliary excretion of methotrexate and increasing plasma concentration [8]. Intestinal and hepatic organic cation transporter 1 (Oct1) expression was increased and decreased, respectively, in rats following repeated administration of RGE ( $1.5 \mathrm{~g} / \mathrm{kg}$ for 7 days) [19]. Although repeated administration of RGE suggested modulation of transporter activity, the systematic pharmacokinetic ginseng-drug interaction on drug transporters and clinical evidence is still limited [20].

In addition to ginseng products, individual ginsenosides can also modulate drug-metabolizing enzymes or transporters. For example, Rb1, the most abundant ginsenoside in RGE, was found to significantly inhibit CYP2C9 (IC 50 value of $2.4 \mu \mathrm{M}$ ), UDP-glucuronosyltransferase (UGT) 1A9 ( $\mathrm{IC}_{50}$ value of $21.3 \mu \mathrm{M}$ ), organic anion transporting polypeptide 1B1 (OATP1B1) (IC 50 value of $33.2 \mu \mathrm{M}$ ), and OATP1B3 ( $\mathrm{IC}_{50}$ value of $\left.4.8 \mu \mathrm{M}\right)$. Other CYP enzymes, UGT enzymes, and transporters were not affected [14]. Ginsenosides could be grouped as protopanaxadiol (PPD)-type ginsenosides and protopanaxatriol (PPT)-type ginsenosides based on their hydroxylation site and their structure effected differentially on the UGT1A9 metabolic activity. F2, Rb1, Rb2, Rc, Rd, and Rg3, PPD-type ginsenosides, inhibited UGT1A9 activity with $\mathrm{IC}_{50}$ values ranging from $6.3 \mu \mathrm{M}$ to $44.0 \mu \mathrm{M}$ but PPT-type ginsenosides such as F1, Re, Rf, and Rg1 did not inhibit UGT1A9 [21]. The PPD-type ginsenoside Rg3 inhibited metabolic activities of UGT1A3 (IC 50 value of $20.9 \mu \mathrm{M})$, UGT1A9 (IC 50 value of $15.1 \mu \mathrm{M})$, and UGT2B7 ( $\mathrm{IC}_{50}$ value of $23.1 \mu \mathrm{M}$ ). The PPD-type ginsenoside Rh2 has been reported to inhibit UGT1A3 with an $\mathrm{IC}_{50}$ value of $37.9 \mu \mathrm{M}$ [22]. The PPD-type ginsenosides Rb1, Rc, and Rd inhibited OATP1B1 and OATP1B3 with $\mathrm{IC}_{50}$ values ranging from $0.2 \mu \mathrm{M}$ to $4.6 \mu \mathrm{M}$. The PPT-type ginsenosides $\operatorname{Rg} 1$ and Re also inhibited OATP1B1 and OATP1B3 with $\mathrm{IC}_{50}$ values ranging from $39.4 \mu \mathrm{M}$ to $133 \mu \mathrm{M}$ [23]. In contrast to the reports of the inhibitory effect of ginsenosides on drug-metabolizing enzymes and transporters, little information is available on the in vivo pharmacokinetic ginsenosides-drug interactions. In addition, the inhibitory effect of PPD-type and PPT-type ginsenosides on drug transport activity has not been studied extensively. Considering the growing evidence of herb-drug interactions involving drug transporters [10], the aim of this study was to investigate the effect of RGE and individual ginsenoside (PPD-type as well as PPT-type) on drug transporters using in vitro cell system and/or in vivo animal model. Specifically, we focused on uptake transporters such as OCTs, OATs, and OATPs as these transporters regulate the tissue distribution, elimination, and pharmacokinetics of natural herbs and xenobiotics [10]. 


\section{Results}

\subsection{Inhibitory Effect of Ginsenosides on Drug Transporters}

The inhibitory effects of ginsenosides on drug transporters were evaluated using HEK293 cells overexpressing OCT1, OCT2, OAT1, OAT3, OATP1B1, OATP1B3 and HEK293-mock cells. First, we measured the uptake of probe substrates into respective transporters in the presence of typical inhibitors of the transporters for the system validation (Figure 1). Triethylammonium (TEA) inhibited OCT1 and OCT2 with $\mathrm{IC}_{50}$ values of $1177 \mu \mathrm{M}$ and $1396 \mu \mathrm{M}$, respectively. Probenecid inhibited OAT1 and OAT3 with $\mathrm{IC}_{50}$ values of $2.33 \mu \mathrm{M}$ and $1.49 \mu \mathrm{M}$, respectively. Rifampin inhibited OATP1B1 and OATP1B3 with $\mathrm{IC}_{50}$ values of $28.6 \mu \mathrm{M}$ and $0.81 \mu \mathrm{M}$, respectively. The results were comparable with $\mathrm{IC}_{50}$ values of TEA reported in the literature (i.e., 1.4-7.4 mM for OCT1 and 2.05 mM for OCT2; 7.6 $\mu \mathrm{M}$ for OAT1 and 4.1 $\mu \mathrm{M}$ for OAT3; 0.8-22.8 $\mu \mathrm{M}$ for OATP1B1 and 0.8-6.4 $\mu \mathrm{M}$ for OATP1B3 [24-28].
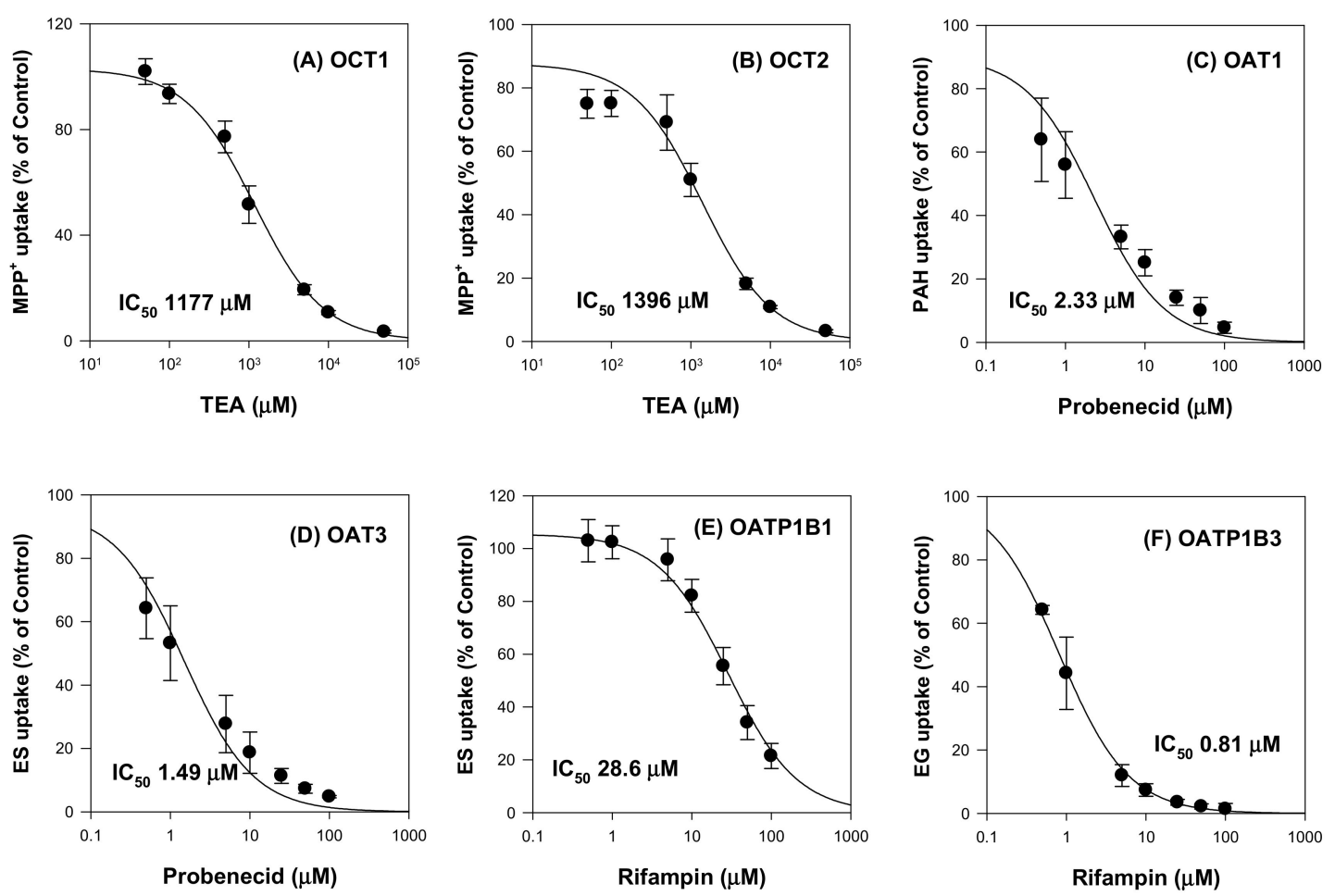

Figure 1. Inhibitory effect of typical inhibitors on the (A) OCT1, (B) OCT2, (C) OAT1, (D) OAT3, (E) OATP1B1, and (F) OATP1B3-mediated uptake. Transporter mediated uptake of probe substrate were calculated by subtracting the uptake in HEK293-mock cells from the uptake in HEK293 cells overexpressing respective transporters. The concentrations and probe substrates were as follows: $0.1 \mu \mathrm{M}\left[{ }^{3} \mathrm{H}\right]$ methyl-4-phenylpyridinium $\left(\mathrm{MPP}^{+}\right)$for OCT1 and OCT2, $0.1 \mu \mathrm{M}\left[{ }^{3} \mathrm{H}\right]$ para-aminohippuric acid (PAH) for OAT1, $0.1 \mu \mathrm{M}\left[{ }^{3} \mathrm{H}\right]$ estrone-3-sulfate (ES) for OAT3 and OATP1B1, and $0.1 \mu \mathrm{M}$ $\left[{ }^{3} \mathrm{H}\right]$ estradiol-17 $\beta$-D-glucuronide (EG) for OATP1B3. The typical inhibitors were used as follows: TEA (0-50 mM) for OCT1 and OCT2, probenecid $(0-250 \mu \mathrm{M})$ for OAT1 and OAT3, and rifampin (0-250 $\mu \mathrm{M})$ for OATP1B1 and OATP1B3. Data are the mean \pm SD from triplicate measurements.

We then evaluated the modulation of drug transporters by ginsenosides. We found that ginsenosides selectively inhibited OATP transport activities but not OCTs and OATs. Ginsenosides Rb1, $\mathrm{Rb} 2, \mathrm{Rc}, \mathrm{Rd}, \mathrm{Rg} 3$, compound $\mathrm{K}, \mathrm{Rh} 2, \mathrm{PPD}, \mathrm{PPT}$, and Rh1 had $\mathrm{IC}_{50}$ values ranging from $1.36 \mu \mathrm{M}$ to $>100 \mu \mathrm{M}$. Most PPD-type ginsenosides inhibited both OATP1B1 and OATP1B3. Among them, tri-glycosylated PPD-type ginsenosides such as $\mathrm{Rb} 1, \mathrm{Rb} 2$, and compound $\mathrm{K}$ inhibited OATP1B3 with higher affinity (i.e., smaller $\mathrm{IC}_{50}$ values) than those of OATP1B1. However, most PPT-type ginsenosides did not inhibit OATP1B1 and OATP1B3 except for PPT (Figures 2 and 3; Table 1). Contrary to the 
results on OATP inhibition, all 12 ginsenosides tested did not significantly inhibit OCT1, OCT2, OAT1, and OAT3 transporters (Table 1).
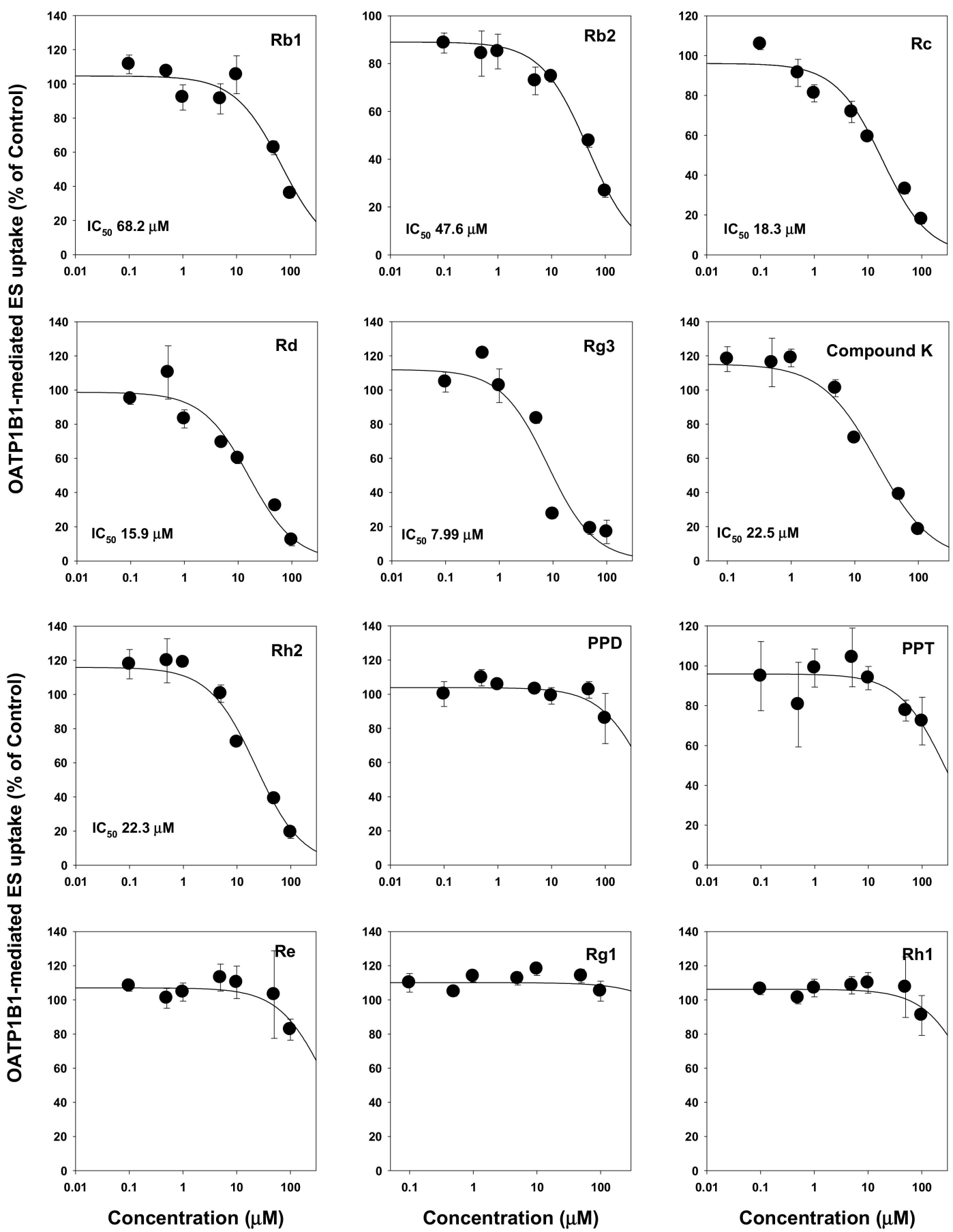

Figure 2. Inhibitory effect of Rb1, Rb2, Rc, Rd, compound $\mathrm{K}, \mathrm{Rg} 3, \mathrm{Rh} 2, \mathrm{PPD}, \mathrm{PPT}$, Re, Rg1, and Rh1 on the OATP1B1-mediated transport of $\left[{ }^{3} \mathrm{H}\right]$ estrone-3-sulfate (ES). OATP1B1-mediated ES uptake were calculated by subtracting $0.1 \mu \mathrm{M}\left[{ }^{3} \mathrm{H}\right] \mathrm{ES}$ uptake in HEK293-mock cells from $0.1 \mu \mathrm{M}\left[{ }^{3} \mathrm{H}\right] \mathrm{ES}$ uptake in HEK293-OATP1B1 cells. Data are the mean \pm SD from triplicate measurements. 

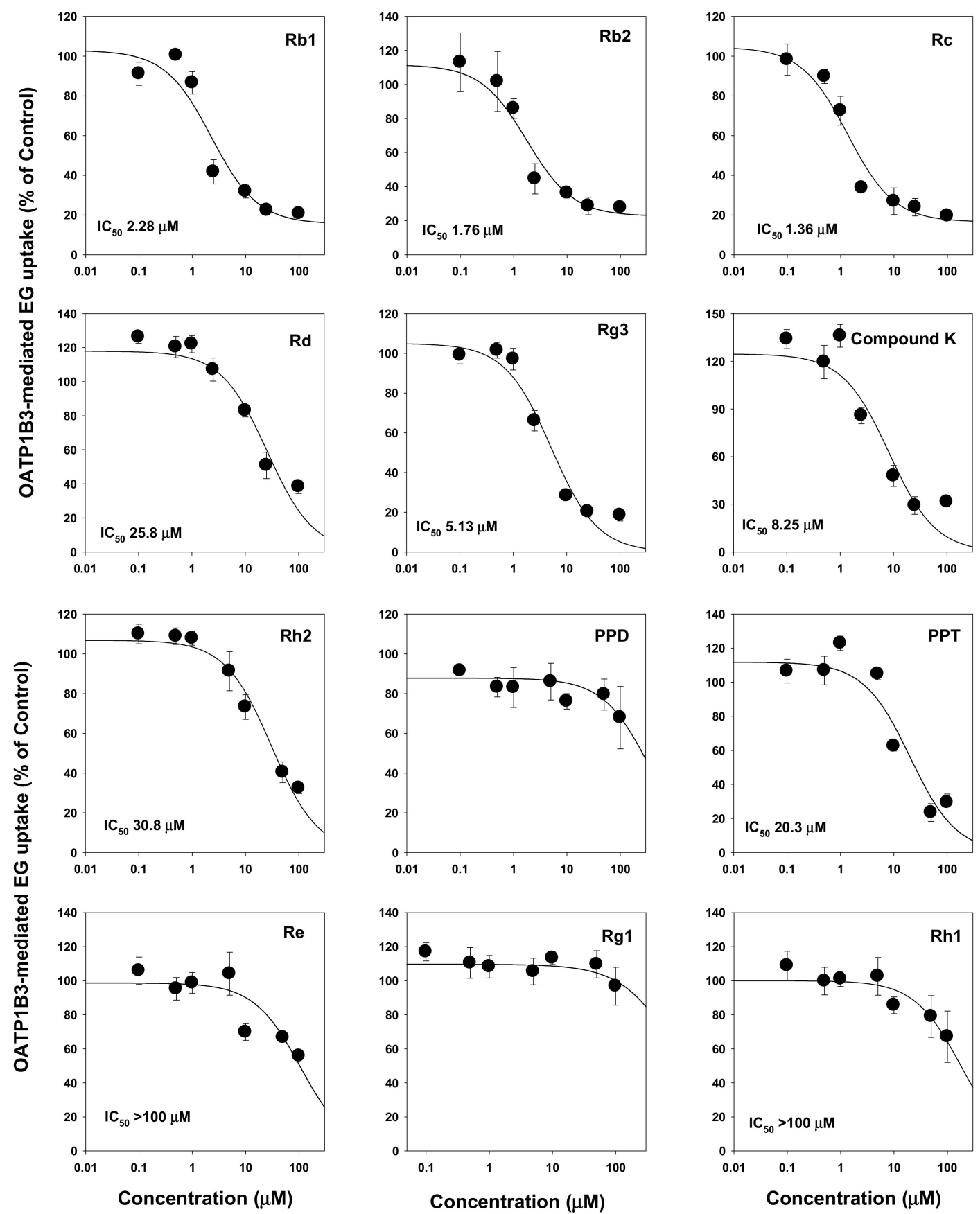

Figure 3. Inhibitory effect of Rb1, Rb2, Rc, Rd, compound K, Rg3, Rh2, PPD, PPT, Re, Rg1, and Rh1 on the OATP1B3-mediated uptake of $\left[{ }^{3} \mathrm{H}\right]$ estradiol-17 $\beta$-D-glucuronide (EG). OATP1B3-mediated EG uptake were calculated by subtracting $0.1 \mu \mathrm{M}\left[{ }^{3} \mathrm{H}\right] \mathrm{EG}$ uptake by HEK293-mock cells from $0.1 \mu \mathrm{M}$ $\left[{ }^{3} \mathrm{H}\right] \mathrm{EG}$ uptake by HEK293-OATP1B3 cells. Data are the mean \pm SD from triplicate measurements. 
Table 1. Inhibitory effect of ginsenosides on drug transporters.

\begin{tabular}{|c|c|c|c|c|c|c|c|}
\hline & \multirow{2}{*}{ Ginsenosides } & \multicolumn{6}{|c|}{$\mathrm{IC}_{50}(\mu \mathrm{M})$} \\
\hline & & OCT1 & OCT2 & OAT1 & OAT3 & OATP1B1 & OATP1B3 \\
\hline \multirow{8}{*}{$\begin{array}{l}\text { PPD-type } \\
\text { ginsenosides }\end{array}$} & $\mathrm{Rb} 1$ & $\mathrm{NI}$ & NI & $\mathrm{NI}$ & $\mathrm{NI}$ & 68.2 & 2.28 \\
\hline & $\mathrm{Rb} 2$ & NI & NI & NI & $\mathrm{NI}$ & 47.6 & 1.76 \\
\hline & $\mathrm{Rc}_{\mathrm{c}}$ & NI & NI & NI & NI & 18.3 & 1.36 \\
\hline & $\mathrm{Rd}$ & NI & NI & NI & NI & 15.9 & 25.8 \\
\hline & $\operatorname{Rg} 3$ & NI & NI & NI & NI & 7.99 & 5.13 \\
\hline & Compound $\mathrm{K}$ & NI & NI & NI & NI & 22.5 & 8.25 \\
\hline & Rh2 & NI & NI & NI & NI & 22.3 & 30.8 \\
\hline & PPD & NI & NI & NI & NI & $\mathrm{NI}$ & NI \\
\hline \multirow{4}{*}{$\begin{array}{l}\text { PPT-type } \\
\text { ginsenosides }\end{array}$} & PPT & NI & NI & NI & NI & NI & 20.3 \\
\hline & $\operatorname{Re}$ & NI & NI & NI & NI & NI & $>100$ \\
\hline & $\operatorname{Rg} 1$ & NI & NI & NI & NI & NI & NI \\
\hline & Rh1 & NI & NI & NI & NI & NI & $>100$ \\
\hline
\end{tabular}

NI: No significant inhibition; >100: weak inhibition but $\mathrm{IC}_{50}$ value over $100 \mu \mathrm{M}$.

\subsection{Valsartan as a Substrate for Oatp Transporter}

Based on the significant inhibitory effect of ginsenosides on OATP1B1 and OATP1B3, we further evaluated the in vivo herb-drug interaction using a substrate drug for both OATP1B1 and OATP1B3. Valsartan was selected as a substrate for both OATP1B1 and OATP1B3 (Figure 4). Valsartan uptake by HEK293 cells expressing OATP1B1 and OATP1B3 was increased by 19.8-fold and 26.1-fold, respectively, compared with the uptake by HEK293-mock cells. OATP1B1- and OATP1B3-mediated valsartan uptake was inhibited by rifampin in a concentration-dependent manner, and the inhibition profile showed $\mathrm{IC}_{50}$ values of $13.8 \mu \mathrm{M}$ and $3.6 \mu \mathrm{M}$, respectively. The results suggested that valsartan is a substrate for OATP1B1 and OATP1B3 transporters and OATP-mediated valsartan uptake was inhibited by the presence of representative OATP inhibitor, rifampin.
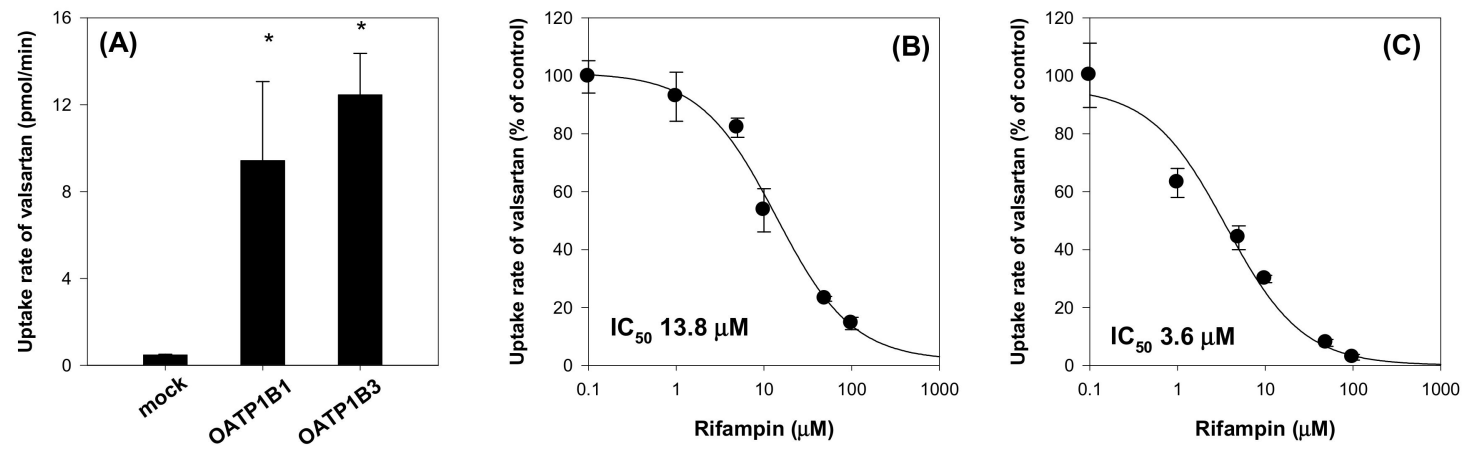

Figure 4. (A) Uptake of valsartan ( $5 \mu \mathrm{M})$ by HEK293-mock cells and HEK293 cells expressing OATP1B1 and OATP1B3. Inhibitory effect of rifampin on the (B) OATP1B1- and (C) OATP1B3-mediated uptake of valsartan. Data points represent the mean \pm SD from triplicate measurements. ${ }^{*} p<0.05$ compared with HEK293-mock cells.

In addition to this, valsartan has been reported to be mainly eliminated via biliary excretion mediated by OATP1B1 and OATP1B3 in human and Oatps in rats. The contribution of Oatp transporters in the hepato-biliary excretion was about $70-85 \%$ in both rats and human $[29,30]$. The results suggest that valsartan could be used as a model drug for investigating OATP (in human) or Oatp (in rats)-mediated herb-drug interaction between valsartan and RGE or ginsenosides. 


\subsection{Effect of RGE on the Pharmacokinetics of Valsartan in Rats}

We initially investigated the effect of rifampin on the valsartan pharmacokinetics following the intravenous injection of valsartan at a dose of $1 \mathrm{mg} / \mathrm{kg}$ as a positive control group and the results were shown in Figure 5A and Table 2.
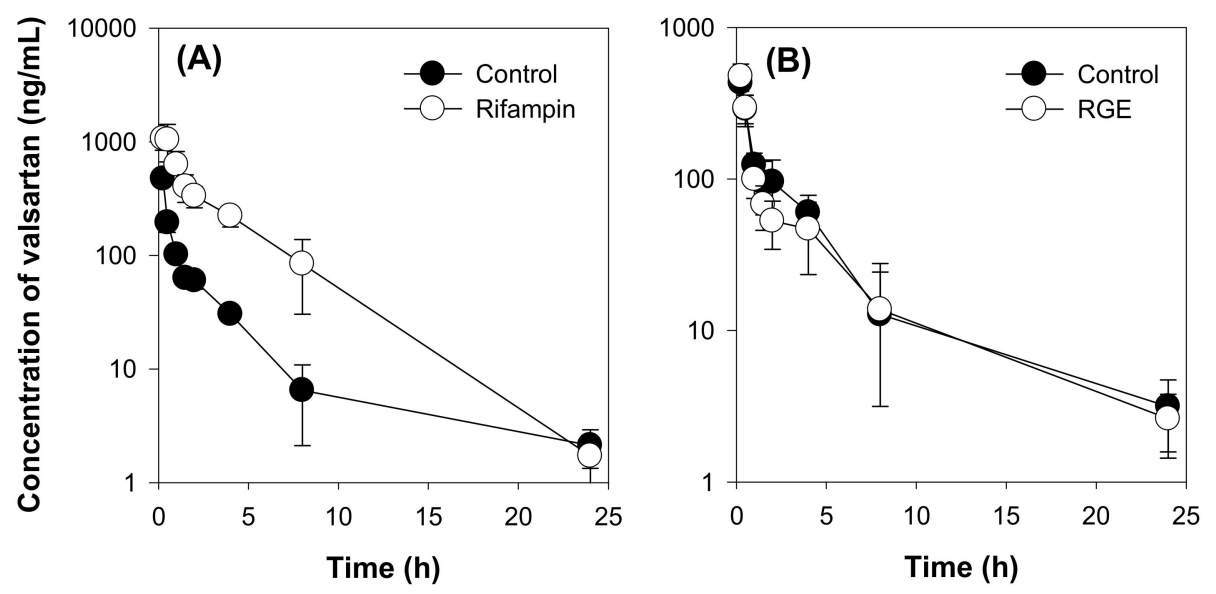

Figure 5. (A) Plasma concentration-time profile of valsartan in the control and rifampin (20 mg/kg) groups following intravenous injection of valsartan at a dose of $1 \mathrm{mg} / \mathrm{kg}$ in rats. (B) Plasma concentration-time profile of valsartan in the control and red ginseng extract (RGE, $1.5 \mathrm{~g} / \mathrm{kg} / \mathrm{day}$ for 7 days) groups following intravenous injection of valsartan at a dose of $1 \mathrm{mg} / \mathrm{kg}$ in rats. Data points represent the mean $\pm \mathrm{SD}$ of four different rats per group.

Table 2. Pharmacokinetic parameters of valsartan following intravenous injection of valsartan at a dose of $1 \mathrm{mg} / \mathrm{kg}$ in rats.

\begin{tabular}{ccccc}
\hline Treatment & \multicolumn{2}{c}{ Valsartan + Rifampin } & \multicolumn{2}{c}{ Valsartan + RGE } \\
\hline PK Parameters & Control & Rifampin & Control & RGE \\
\hline $\mathrm{T}_{1 / 2}(\mathrm{~h})$ & $4.48 \pm 1.24$ & $2.79 \pm 0.32 *$ & $4.55 \pm 0.98$ & $4.59 \pm 0.73$ \\
$\mathrm{C}_{0}(\mathrm{ng} / \mathrm{mL})$ & $1169.59 \pm 118.78$ & $1633.08 \pm 1308.67$ & $647.53 \pm 50.49$ & $781.47 \pm 211.04$ \\
$\mathrm{AUC}_{24 \mathrm{~h}}(\mathrm{ng} \cdot \mathrm{h} / \mathrm{mL})$ & $667.56 \pm 219.43$ & $3318.65 \pm 809.25^{*}$ & $859.36 \pm 234.46$ & $776.59 \pm 228.82$ \\
$\mathrm{AUC} C_{\infty}(\mathrm{ng} \cdot \mathrm{h} / \mathrm{mL})$ & $681.03 \pm 215.12$ & $3325.83 \pm 807.91^{*}$ & $881.62 \pm 247.34$ & $794.48 \pm 226.13$ \\
$\mathrm{MRT}(\mathrm{h})$ & $2.99 \pm 0.47$ & $3.37 \pm 0.83$ & $3.76 \pm 1.16$ & $3.81 \pm 0.05$ \\
$\mathrm{CL}(\mathrm{mL} / \mathrm{min} / \mathrm{kg})$ & $25.96 \pm 6.30$ & $15.55 \pm 5.69^{*}$ & $20.03 \pm 5.48$ & $22.47 \pm 7.12$ \\
$\mathrm{Vd}(\mathrm{mL} / \mathrm{kg})$ & $78.30 \pm 25.66$ & $55.03 \pm 26.29^{*}$ & $72.16 \pm 15.37$ & $85.38 \pm 25.82$ \\
\hline
\end{tabular}

Data represent mean $\pm \mathrm{SD}$ of four rats per group. ${ }^{*} p<0.05$ compared with control group. $\mathrm{T}_{1 / 2}$ : elimination half-life; $\mathrm{C}_{0}$ : initial plasma concentration at $1 \mathrm{~h} ; \mathrm{AUC}_{24 \mathrm{~h}}$ or $\mathrm{AUC}_{\infty}$ : Area under plasma concentration-time curve from zero to 24 h or infinity; MRT: mean residence time; CL: systemic clearance; Vd: Volume of distribution.

The plasma concentration of valsartan was increased by co-treatment with rifampin, a typical inhibitor of OATP or Oatp transporters. Thus, pharmacokinetic parameters such as the area under the plasma concentration-time curve $\left(\mathrm{AUC}_{24 \mathrm{~h}}\right.$ and $\left.A U C_{\infty}\right)$ values were significantly higher than those of the control group. The clearance $(C L)$ and volume of distribution $\left(V_{d}\right)$ of valsartan were decreased by rifampin co-administration. Taken together, rifampin inhibited OATP transport activity in vivo, thus decreasing the hepatic elimination of valsartan and increasing the plasma concentration of this drug. However, compared with the control group, repeated administration of RGE $(1.5 \mathrm{~g} / \mathrm{kg} / \mathrm{day}$ for 7 days) did not affect the plasma concentration and pharmacokinetic parameters of valsartan (Figure 5B and Table 2). The results suggest that repeated RGE treatment did not inhibited Oatp transport activity in rats.

To explain the lack of herb-drug interaction between RGE and valsartan, we measured the plasma concentrations of ginsenosides following repeated administration of RGE using the previously developed analytical method by LC-MS/MS [19,31]. Among the 14 ginsenosides examined (Rb1, Rb2, 
Rc, Rd, Rh2, Rg3, F2, compound K, PPD, Re, Rh1, Rg1, F1, and PPT), 6 ginsenosides were detected in the plasma samples and the plasma concentrations of the 6 ginsenosides are shown in Figure 6 . The plasma concentrations of the ginsenosides $\mathrm{Rb} 1, \mathrm{Rb} 2, \mathrm{Rc}$, and $\mathrm{Rd}$ in rats after multiple administration of $\mathrm{RGE}$ $(1.5 \mathrm{~g} / \mathrm{kg} /$ day) for 1 week were consistent with previous results [8,19]. The ginsenosides $\mathrm{Rh} 2, \mathrm{Rg} 3$, F2, and compound K (intermediate metabolites of PPD-type ginsenosides [32], were not detected. PPD, a final metabolite of PPD-type ginsenosides, was detected in the rat plasma and showed a slow elimination process (Figure 6E and Table 3). Similarly, Re, Rh1, Rg1, and F1 (PPT-type ginsenosides and their intermediate metabolites [32]) were not detected in the rat plasma. PPT, a final metabolite of PPT-type ginsenosides, was detected and also showed a slow elimination process (Figure 6F and Table 3).
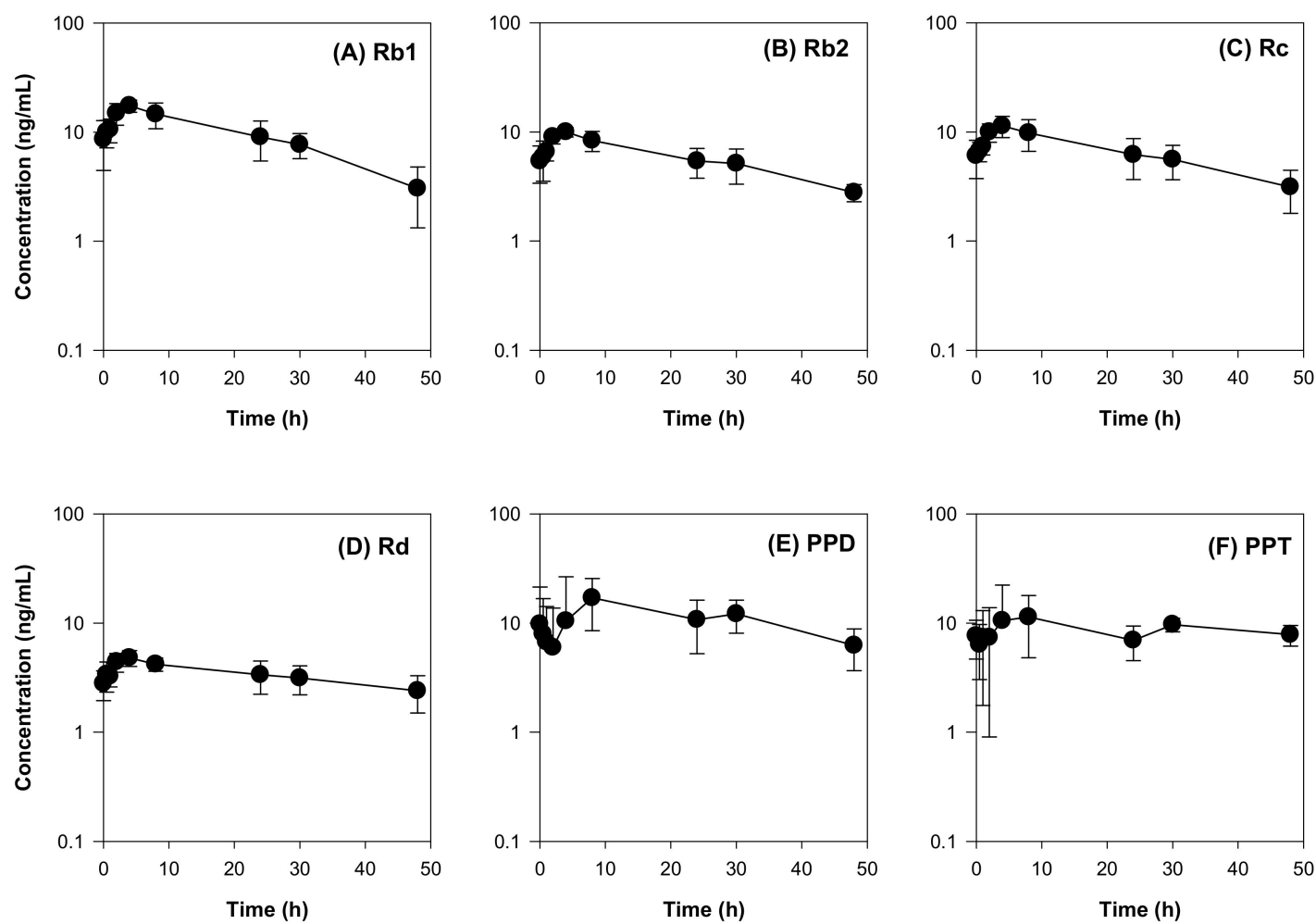

Figure 6. Plasma concentration-time profiles of the ginsenosides (A) Rb1, (B) Rb2, (C) Rc, (D) Rd, (E) PPD, and (F) PPT in the rat plasma after 1-week repeated administration of red ginseng extract (RGE). Data represent the mean \pm SD of four rats.

Table 3. Pharmacokinetic parameters of ginsenosides in the rat plasma after 1-week repeated administration of red ginseng extract (RGE).

\begin{tabular}{cccccc}
\hline \multirow{2}{*}{ Ginsenosides } & \multicolumn{5}{c}{ Pharmacokinetic Parameters } \\
\cline { 2 - 6 } & $\begin{array}{c}\text { AUC } \\
\text { (ng.h/mL) }\end{array}$ & $\mathbf{C}_{\mathbf{m a x}}(\mathbf{n g} / \mathbf{m L})$ & $\mathbf{T}_{\max }(\mathbf{h})$ & MRT (h) & $\mathbf{T}_{\mathbf{1 / 2}} \mathbf{( h )}$ \\
\hline $\mathrm{Rb} 1$ & $454.57 \pm 111.33$ & $17.84 \pm 2.34$ & $3.33 \pm 1.15$ & $17.13 \pm 2.09$ & $16.87 \pm 5.81$ \\
$\mathrm{Rb} 2$ & $282.80 \pm 58.90$ & $10.02 \pm 1.04$ & $3.33 \pm 1.15$ & $18.61 \pm 1.43$ & $30.19 \pm 5.48$ \\
$\mathrm{Rc}$ & $320.75 \pm 97.23$ & $11.67 \pm 2.49$ & $3.33 \pm 1.15$ & $18.35 \pm 1.89$ & $24.24 \pm 7.51$ \\
$\mathrm{Rd}$ & $163.83 \pm 39.07$ & $5.10 \pm 0.74$ & $2.17 \pm 1.76$ & $20.84 \pm 1.68$ & $43.49 \pm 17.54$ \\
$\mathrm{PPD}$ & $542.01 \pm 141.09$ & $20.56 \pm 9.47$ & $16.50 \pm 12.48$ & $21.56 \pm 3.31$ & $26.95 \pm 18.33$ \\
$\mathrm{PPT}$ & $429.91 \pm 105.75$ & $16.97 \pm 8.99$ & $16.50 \pm 12.48$ & $23.12 \pm 2.26$ & $46.38 \pm 13.27$ \\
\hline
\end{tabular}

Data represent mean \pm SD of four rats per group. AUC: area under the plasma concentration-time curve from 0 to 48 h $C_{\max }$ : maximum plasma concentration; $\mathrm{T}_{\max }$ : time to reach $\mathrm{C}_{\max }$; $\mathrm{MRT}$ : Mean residence time; $\mathrm{T}_{1 / 2}$ : Half-life.

As shown in Table 3. the maximum plasma concentrations of $R b 1, R b 2, R c, R d, P P D$, and PPT were $17.84 \pm 2.34 \mathrm{ng} / \mathrm{mL}(15.8 \mathrm{nM}), 10.02 \pm 1.04 \mathrm{ng} / \mathrm{mL}(9.1 \mathrm{nM}), 11.67 \pm 2.49(10.6 \mathrm{nM})$, 
$5.10 \pm 0.74 \mathrm{ng} / \mathrm{mL}$ (5.3 nM), $20.56 \pm 9.47 \mathrm{ng} / \mathrm{mL}(48.4 \mathrm{nM})$, and $16.97 \pm 8.99 \mathrm{ng} / \mathrm{mL}$ (38.5 nM), respectively. These concentrations might be far below the $\mathrm{IC}_{50}$ values required for the inhibition of Oatp transport activity and, therefore, the plasma PPD-type ginsenoside could not inhibit Oatp-mediated biliary excretion of valsartan effectively.

\subsection{Effect of Ginsenoside Rc on the Pharmacokinetics of Valsartan in Rats}

We further investigated herb-drug interaction between valsartan and individual ginsenoside. At first, the inhibitory effect of ginsenoside Rb1, Rb2, and Rc on the OATP1B1 and OATP1B3-mediated valsartan uptake was measured. Ginsenoside $\mathrm{Rb} 1, \mathrm{Rb} 2$, and Rc was selected considering its stability and high plasma concentation in rat plasma (based on Figure 6) and in human plasma [31,33] as well as its low $\mathrm{IC}_{50}$ value for OATP1B3 inhibition $(2.28 \mu \mathrm{M}, 1.76 \mu \mathrm{M}$, and $1.36 \mu \mathrm{M}$, respectively, Figure 3). As shown in Figure 7, Rb1, Rb2, and Rc inhibited both OATP1B1 and OATP1B3-mediated valsartan uptake in a concentration dependent manner and yielded $\mathrm{IC}_{50}$ values of 8.8-24.1 $\mu \mathrm{M}$ for OATP1B1 and 1.9-5.1 $\mu \mathrm{M}$ for OATP1B3. The results higher affinity of Rb1, Rb2, and Rc to OATP1B3 than OATP1B1 and the lowest $\mathrm{IC}_{50}$ value was shown in Rc inhibition on OATP1B3-mediated uptake of valsartan was consistent with the previous results (Figures 2 and 3).
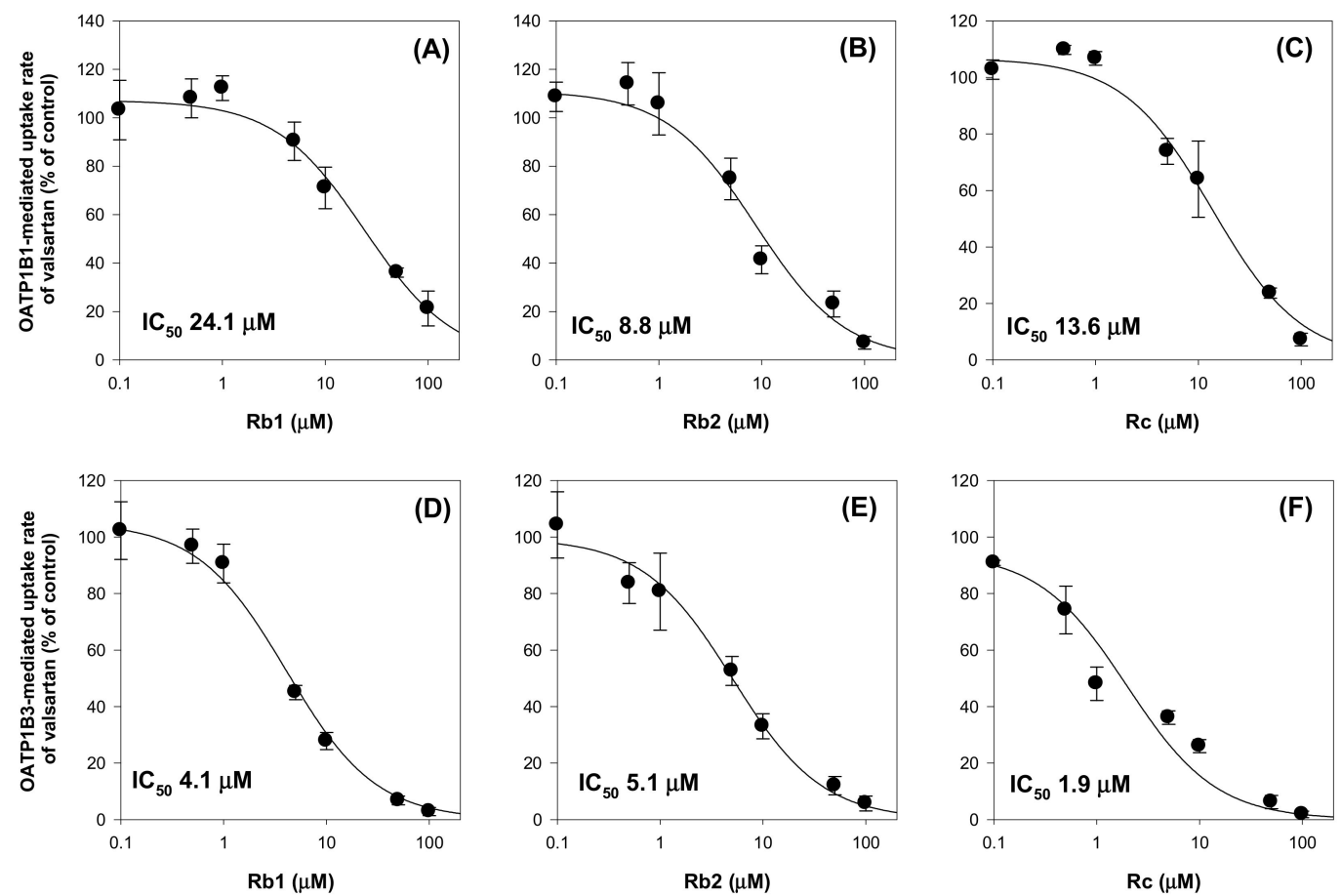

Figure 7. Inhibitory effect of $\operatorname{Rb} 1(\mathbf{A}, \mathbf{D}), \operatorname{Rb} 2(\mathbf{B}, \mathbf{E})$, and $\operatorname{Rc}(\mathbf{C}, \mathbf{F})$ on the OATP1B1- and OATP1B3-mediated uptake of valsartan. OATP1B1- and OATP1B3-mediated valsartan uptake was calculated by subtracting valsartan uptake $(5 \mu \mathrm{M})$ by HEK293-mock cells from valsartan uptake $(5 \mu \mathrm{M})$ by HEK293-OATP1B1 and -OATP1B3 cells, respectively. Data points represent the mean \pm SD from triplicate measurements.

Next, we investigated whether the high plasma concentration of individual ginsenoside (Rc) above the $\mathrm{IC}_{50}$ value required for the inhibition of OATP/Oatp transporters could induce the in vivo herb-drug interactions. To achieve the highest and stable plasma concentration of Rc, it was injected intravenously for 5 days before the administration of valsartan. As shown in Figure $8 \mathrm{~B}$, the Rc concentration ranged from $7.8 \mu \mathrm{M}$ to $34.1 \mu \mathrm{M}$. However, the plasma concentration of valsartan was not affected by Rc treatment (Figure 8A), and all pharmacokinetic parameters were not statistically different between the two groups (control group vs. Rc group) (Table 4). The results suggest that Rc did not inhibit the hepatic elimination of valsartan mediated by Oatp transporters in vivo even though 
the plasma concentration of $\mathrm{Rc}$ was greater than the $\mathrm{IC}_{50}$ value of Rc required for Oatp transport activity inhibition.
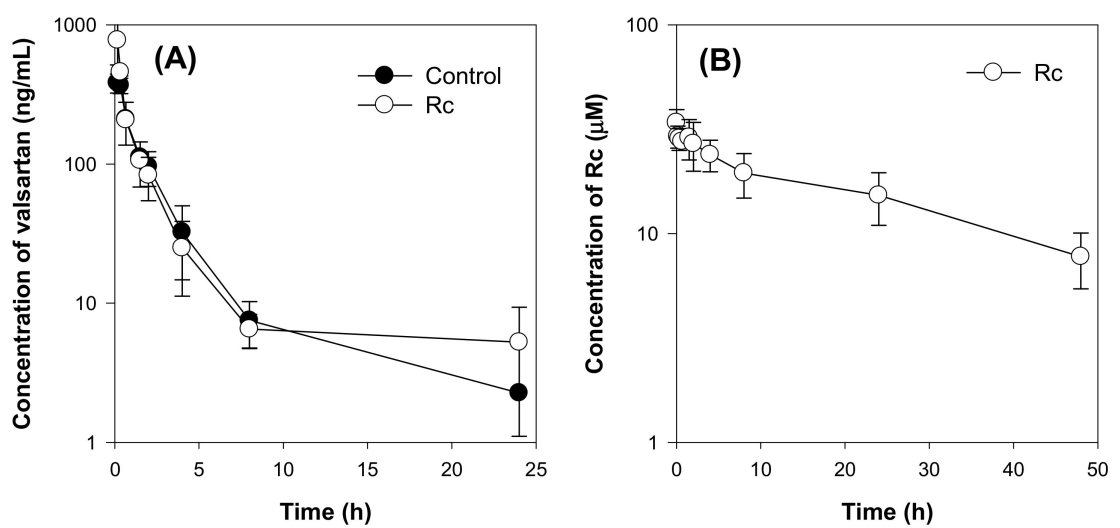

Figure 8. (A) Plasma concentration-time profile of valsartan in the control and Rc groups following intravenous injection of valsartan at a dose of $1 \mathrm{mg} / \mathrm{kg}$. Rc was injected intravenously for 5 days at a dose of $3 \mathrm{mg} / \mathrm{kg} /$ day. (B) Plasma concentration-time profile of Rc in the Rc group. Data points represent the mean \pm SD of three different rats per group.

Table 4. Pharmacokinetic parameters of valsartan and Rc following intravenous injection of valsartan at a dose of $1 \mathrm{mg} / \mathrm{kg}$ in rats.

\begin{tabular}{ccccc}
\hline & Valsartan & \multicolumn{2}{c}{ Rc } \\
\hline Parameters & Control & Rc Treatment & Parameters & Rc Treatment \\
\hline $\mathrm{T}_{1 / 2}(\mathrm{~h})$ & $2.41 \pm 1.30$ & $3.30 \pm 1.51$ & $\mathrm{~T}_{1 / 2}(\mathrm{~h})$ & $27.51 \pm 4.26$ \\
$\mathrm{C}_{0}(\mathrm{ng} / \mathrm{mL})$ & $400.66 \pm 77.85$ & $1451.25 \pm 998.21$ & $\mathrm{C}_{0}(\mu \mathrm{M})$ & $34.04 \pm 5.22$ \\
$\mathrm{AUC}_{24 \mathrm{~h}}(\mathrm{ng} \cdot \mathrm{h} / \mathrm{mL})$ & $639.41 \pm 80.71$ & $808.86 \pm 111.90$ & $\mathrm{AUC}_{24 \mathrm{~h}}(\mu \mathrm{M} \cdot \mathrm{h})$ & $748.59 \pm 184.79$ \\
$\mathrm{AUC}_{\infty}(\mathrm{ng} \cdot \mathrm{h} / \mathrm{mL})$ & $657.34 \pm 84.89$ & $836.42 \pm 112.34$ & $\mathrm{AUC}_{\infty}(\mu \mathrm{M} \cdot \mathrm{h})$ & $1064.50 \pm 324.96$ \\
$\mathrm{MRT}(\mathrm{h})$ & $2.27 \pm 0.67$ & $2.94 \pm 1.52$ & $\mathrm{MRT}(\mathrm{h})$ & $38.50 \pm 5.11$ \\
$\mathrm{CL}(\mathrm{mL} / \mathrm{h} / \mathrm{kg})$ & $25.66 \pm 3.50$ & $20.18 \pm 2.86$ & & \\
$\mathrm{Vd}(\mathrm{L} / \mathrm{kg})$ & $57.14 \pm 13.24$ & $57.65 \pm 27.32$ & & \\
\hline
\end{tabular}

Data represent mean $\pm S D$ of three rats per group $T_{1 / 2}$ : elimination half-life; $C_{0}$ : initial plasma concentration at $1 \mathrm{~h}$; $\mathrm{AUC}_{24 \mathrm{~h}}$ or $\mathrm{AUC}_{\infty}$ : Area under plasma concentration-time curve from zero to $24 \mathrm{~h}$ or infinity; MRT: mean residence time; CL: systemic clearance; Vd: Volume of distribution.

To investigate the cause of the minimal herb-drug interaction between Rc and valsartan, we measured the plasma and liver distribution of Rc following intravenous injection of Rc. As shown in Figure 9A, Rc was not widely distributed to the liver; thus, the liver concentration of Rc was lower than the plasma concentration of Rc and the liver-to-plasma concentration ratio of Rc was in the range of 0.13-0.2. In addition, these tri-glycosylated ginsenosides showed high protein binding in rat plasma and liver homogenates (Figure 9B). When calculated free Rc concentration in our system, free Rc concentration was estimated to be $0.08-0.34 \mu \mathrm{M}$ in the rat plasma and $0.07-0.14 \mu \mathrm{M}$ in the rat liver. As Oatp transporters are located in the sinusoidal membrane of hepatocytes, the low hepatic distribution and high protein binding of Rc may contribute to the negative inhibitory effect of Rc on Oatp transporters in vivo, which might result in the negligible pharmacokinetic interaction between Rc and valsartan. Similarly, limited herb-drug interaction between valsartan and ginsenoside $\mathrm{Rb} 1$ and $\mathrm{Rb} 2$ would be expected based on their similarity in the structure, protein binding features, and inhibitory effect on OATP transporters (Figures 7 and 9B, Table 1). 


\section{(A) Liver distribution}

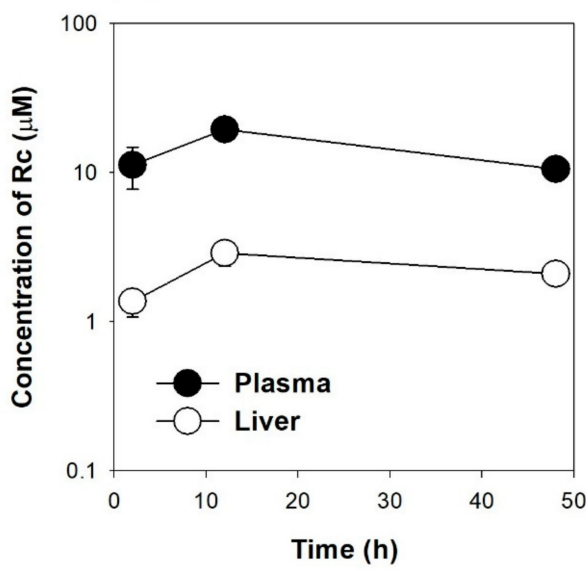

(B) Protein binding

\begin{tabular}{c|cc}
\hline & \multicolumn{2}{|c}{ Protein binding (\%) } \\
& Plasma & Liver \\
\hline Rb1 & $99.8 \pm 0.008$ & $99.6 \pm 0.1$ \\
Rb2 & $99.9 \pm 0.004$ & $99.6 \pm 0.1$ \\
Rc & $99.9 \pm 0.007$ & $99.5 \pm 0.02$ \\
\hline
\end{tabular}

Figure 9. (A) Plasma $(\bullet)$ and liver $(\bigcirc)$ concentrations of Rc following intravenous injection of Rc at a dose of $3 \mathrm{mg} / \mathrm{kg}$. (B) Protein binding of Rb1, Rb2, and Rc in the rat plasma and liver homogenates using a rapid equilibrium dialysis device. Data were expressed as the mean \pm SD of three different rats or triplicated measurements.

\section{Discussion}

In the present study, the inhibitory effect of 12 ginsenosides $(\mathrm{Rb} 1, \mathrm{Rb} 2, \mathrm{Rc}, \mathrm{Rd}$, compound $\mathrm{K}$, Rg3, Rh2, PPD, PPT, Re, Rg1, and Rh1) on HEK293 cells overexpressing drug transporters such as OCT1, OCT2, OAT1, OAT3, OATP1B1, and OATP1B3 was evaluated. The transport activity of OCT1, OCT2, OAT1, and OAT3 was not modulated by the 12 ginsenosides. However, Rb1, Rb2, Rc, Rd, Rg3, compound $\mathrm{K}$, and Rh2 (PPD-type ginsenosides) inhibited OATP1B1 with $\mathrm{IC}_{50}$ values of 7.99-68.2 $\mu \mathrm{M}$. PPD-type ginsenosides also inhibited OATP1B3 transport activity with higher affinity. The $\mathrm{IC}_{50}$ values of PPD-type ginsenosides for OATP1B3 inhibition ranged from $1.36 \mu \mathrm{M}$ to $30.8 \mu \mathrm{M}$. On the other hand, PPT-type ginsenosides such as Re, Rg1, Rh1, and PPT did not inhibit OATP1B1 transport activity, and PPT and Rh1 inhibited OATP1B3 with $\mathrm{IC}_{50}$ values of $20.3 \mu \mathrm{M}$ and $>100 \mu \mathrm{M}$, respectively. These results suggest that PPD-type ginsenosides might induce herb-drug interactions via OATP1B1 and OATP1B3 inhibition.

This possible herb-drug interaction led us to investigate OATP-mediated in vivo pharmacokinetic herb-drug interactions because OATPs play important roles in the intestinal absorption and hepatic uptake of various therapeutic reagents. And a lot of clinically relevant herb-drug interactions and drug-drug interactions have been reported to be caused by the inhibition of OATPs [34]. For example, gemfibrozil and cyclosporine can increase the plasma exposure of pravastatin, pitavastatin, and atorvastatin through the inhibition of hepatic OATPs [34]. Quercetin (1500 mg/day for 7 days) and grapefruit juice ( $300 \mathrm{~mL}$ of pure juice) can inhibit intestinal OATP, thereby decreasing the absorption of talinolol [35]. Green tea and its marker component, epigallocatechin gallate, can also suppress the absorption of naldolol and rosuvastatin via the inhibition of intestinal OATP [35]. Given the importance of OATP (in human) and Oatp (in rat) in the pharmacokinetics and biliary excretion of valsartan [29,30], we monitored Oatp-mediated in vivo herb-drug interactions using valsartan as a substrate for Oatps in rats. The results revealed that the repeated administration of RGE and high dose of Rc did not significantly induce herb-drug interactions involving valsartan (Figures 5 and 8).

Among PPD-type ginsenosides that inhibited in vitro OATP function, ginsenosides $\mathrm{Rb} 1, \mathrm{Rb}$, and Rc demonstrated high affinity for OATP1B3 inhibition (1.9-5.1 $\mu \mathrm{M}$ for OATP1B3; Figure 7). However, the maximum plasma concentrations $\left(\mathrm{C}_{\max }\right)$ of $\mathrm{Rb} 1, \mathrm{Rb} 2$, and $\mathrm{Rc}$ in rats were in the range of $5.3-15.8 \mathrm{nM}$ following repeated administration of RGE ( $1.5 \mathrm{~g} / \mathrm{kg} /$ day) for 7 days (Figure 6) and $\mathrm{C}_{\max }$ of $\mathrm{Rb} 1, \mathrm{Rb} 2$, and $\mathrm{Rc}$ in human were 6.2-12.7 $\mathrm{nM}$ following repeated administration of RGE ( $3 \mathrm{~g} / \mathrm{day}$ ) for 14 days [31]. The selected RGE dose in this study is in the range of effective dose without significant toxicity and showed similar plasma concentrations of $\mathrm{Rb} 1, \mathrm{Rb} 2$, and $\mathrm{Rc}(5.3-15.8 \mathrm{nM}$ in rats and 6.2-12.7 
$\mathrm{nM}$ in human subjects) $[19,33]$. In numerous animal studies, the RGE dose has ranged from $200 \mathrm{mg} / \mathrm{kg}$ to $2.0 \mathrm{~g} / \mathrm{kg}$ (i.e., 3-15 mg/kg of total ginsenosides) [36,37]. In human studies, RGE was administered to diabetic patients for 4 to 24 weeks at doses of 2.7-6.0g/day, which usually contained 50-100 mg ginsenosides/day [20,38]. The $\mathrm{C}_{\max }$ values following oral administration of ginseng product in both rats and human would be far below the $\mathrm{IC}_{50}$ values required for OATP transport activity inhibition, which contribute to the limited herb-drug interaction between ginseng and OATP/Oatp substrates.

Co-administration of valsartan and Rc ( $3 \mathrm{mg} / \mathrm{kg} / \mathrm{day}$, iv for 5 days) resulted in the lack of herb-drug interaction between $\mathrm{Rc}$ and valsartan. The plasma concentration was ranged from $7.8 \mu \mathrm{M}$ to $34.1 \mu \mathrm{M}$ but unbound fraction of tri-glycosylated PPD-type ginsenosides ( $\mathrm{Rb} 1, \mathrm{Rb} 2$, and $\mathrm{Rc}$ ) was very low $(0.1-0.2 \%$ in rat plasma, $0.4-0.5 \%$ in rat liver; Figure $9 \mathrm{~B})$. Moreover, the tri-glycosylated ginsenosides are hydrophilic and bulky and, thus, they are difficult to be readily distributed in the liver tissue. Taken together, high protein binding and limited liver distribution of tri-glycosylated PPD-type ginsenosides ( $\mathrm{Rb} 1, \mathrm{Rb} 2$, and $\mathrm{Rc}$ ) might contribute to the lack of in vivo pharmacokinetic herb-drug interactions involving valsartan in rats although their plasma concentration was maximized following repeated intravenous injection of single ginsenoside. Jiang et al. [23] reported that the unbound fraction of PPD-type ginsenosides was very low (0.4-0.9\% in Rb1, Rc, and $\mathrm{Rd}$ ) in the human plasma. Based on the similarity in the structure and protein binding features between rats and human and inhibitory effect on OATP transporters of $\mathrm{Rb} 1, \mathrm{Rb} 2$, and $\mathrm{Rc}$, limited herb-drug interaction between valsartan and ginsenoside $\mathrm{Rb} 1, \mathrm{Rb} 2$, and Rc would be expected in human. In case of co-administration of valsartan and rifampin, a significant drug interaction between valsartan and rifampin was found (Figure 5A) because unbound concentration of rifampin $(4.7-22.9 \mu \mathrm{M})$ would exceed the $\mathrm{IC}_{50}$ values required for OATP inhibition considering the plasma concentration (over $5 \mu \mathrm{g} / \mathrm{mL}$ for $12 \mathrm{~h}$ and $\mathrm{C}_{\max }$ of $15.7-24.5 \mu \mathrm{g} / \mathrm{mL}$ ) and protein binding of rifampin (23.1\%) in rats following oral administration of rifampin $20 \mathrm{mg} / \mathrm{kg}[23,39,40]$.

Clinical herb-drug interactions between ginseng or ginsenosides and OATP1B1 or OATP1B3 have not been fully investigated. Nevertheless, in a previous study, single or repeated administration of red ginseng solution ( $>60 \%$ dried ginseng, three pouches/day once or for 2 weeks; equivalent to $85 \mathrm{mg}$ total ginsenosides) did not have clinically significant inhibitory effects on the pharmacokinetics of pitavastatin, a selective substrate for OATP1B1 [14]. Furthermore, the clinically relevant pharmacokinetic ginseng or ginsenosides-valsartan interaction may not be caused based on the maximum concentrations of ginsenosides $\mathrm{Rb} 1, \mathrm{Rb} 2$, and $\mathrm{Rc}(6.2-12.7 \mathrm{nM}$ ) in human blood after repeated administration of red ginseng extract at high daily dose (3 g/day) [14,41]. In addition, 82-year-old male patient who took atorvastatin $(80 \mathrm{mg})$, atenolol (50 mg), and aspirin (100 $\mathrm{mg})$ reported drug-induced liver injury after concomitant ginseng intake. The patient's symptoms regarding liver injury were resolved within 2 months after the cessation of both atorvastatin and the ginseng product [42]. After that, the case of liver injury might be deduced by the impaired elimination of atorvastatin through the inhibition of CYP3A4 and/or OATP1B1 activity by ginseng product [42]. However, based on the present results, the atorvastatin-induced liver injury in this patient may not be attributed to ginseng-atorvastatin interactions involving OATP1B1.

The benefits of ginseng and ginsenosides have been reported in cardiovascular diseases [2]. Ginseng is also widely used for individuals with cardiovascular risk factors such as hypertension and hypercholesterolemia [2]. The ginsenoside Rc has been found to have analgesic, anti-allergic, anti-tumor, and sedative effects [43]. The ginsenoside Rc may also be a strong anti-diabetic agent because it can markedly enhance glucose uptake [44]. Therefore, in conclusion, the findings showing the lack of herb-drug interactions between RGE or ginsenoside Rc and valsartan would provide useful information for patients taking anti-hypertensive, anti-diabetics, anti-tumor drugs such as valsartan and repaglinide that are substrate for OATPs transporters. 


\section{Materials and Methods}

\subsection{Materials}

RGE was purchased from the Punggi Ginseng Cooperative Association (Youngjoo, Kyungpook, Korea). The ginsenosides Rb1, Rb2, Rc, Rd, Rg1, Rg3, Rh1, Rh2, compound K, Re, PPD, and PPT were purchased from the Ambo Institute (Daejeon, Korea). Berberine, caffeine, valsartan, probenecid, rifampin, TEA, sodium dodecyl sulfate (SDS), and Hank's balanced salt solution (HBSS) were obtained from Sigma-Aldrich (St. Louis, MO, USA). Dulbecco's modified Eagle's medium (DMEM), fetal bovine serum (FBS), non-essential amino acids, and poly-D-lysine-coated 96-well plates were purchased from Corning Life Sciences (Woburn, MA, USA). $\left[{ }^{3} \mathrm{H}\right]$ Methyl-4-phenylpyridinium $\left(\left[{ }^{3} \mathrm{H}\right] \mathrm{MPP}^{+}\right.$; $2.9 \mathrm{TBq} / \mathrm{mmol}),\left[{ }^{3} \mathrm{H}\right]$ para-aminohippuric acid $\left(\left[{ }^{3} \mathrm{H}\right] \mathrm{PAH} ; 0.13 \mathrm{TBq} / \mathrm{mmol}\right),\left[{ }^{3} \mathrm{H}\right]$ estrone-3-sulfate $\left(\left[{ }^{3} \mathrm{H}\right] \mathrm{ES}\right.$; $2.1 \mathrm{TBq} / \mathrm{mmol})$, and $\left[{ }^{3} \mathrm{H}\right]$ estradiol-17 $\beta$-D-glucuronide $\left(\left[{ }^{3} \mathrm{H}\right] \mathrm{EG} ; 2.2 \mathrm{TBq} / \mathrm{mmol}\right)$ were purchased from Perkin Elmer Inc. (Boston, MA, USA). Acetonitrile, methanol, and water were obtained from Fisher Scientific Co. (Fair Lawn, NJ, USA). All other chemicals and solvents were of reagent or analytical grade.

\subsection{Inhibitory Effects of Ginsenosides on Drug Transporters}

HEK293 cells overexpressing the OCT1, OCT2, OAT1, OAT3, OATP1B1, and OATP1B3 transporters (HEK293-OCT1, -OCT2, -OAT1, -OAT3, -OATP1B1, and -OATP1B3, respectively) and HEK293-mock cells (Corning Life Sciences; Woburn, MA, USA) were used and characterized as previously described $[26,45,46]$.

HEK293 cells overexpressing drug transporters and HEK293-mock cells were seeded in poly-D-lysine-coated 96-well plates at a density of $10^{5}$ cells/well and were cultured in DMEM supplemented with 10\% FBS, $5 \mathrm{mM}$ non-essential amino acids, and $2 \mathrm{mM}$ sodium butyrate in a humidified atmosphere with $8 \% \mathrm{CO}_{2}$ at $37{ }^{\circ} \mathrm{C}$. For the experiments, the growth medium was discarded after $24 \mathrm{~h}$, and the attached cells were washed with HBSS and pre-incubated for $10 \mathrm{~min}$ in HBSS at $37^{\circ} \mathrm{C}$.

To examine the effects of ginsenosides and typical inhibitors on transporter activity, aliquots $(100 \mu \mathrm{L})$ of HBSS containing the probe substrate and ginsenosides or typical inhibitors were added to the cells after aspirating pre-incubated HBSS. The concentrations and probe substrates were as follows: $0.1 \mu \mathrm{M}$ $\left[{ }^{3} \mathrm{H}\right] \mathrm{MPP}^{+}$for OCT1 and OCT2, $0.1 \mu \mathrm{M}\left[{ }^{3} \mathrm{H}\right] \mathrm{PAH}$ for OAT1, $0.1 \mu \mathrm{M}\left[{ }^{3} \mathrm{H}\right] \mathrm{ES}$ for OAT3 and OATP1B1, and $0.1 \mu \mathrm{M}\left[{ }^{3} \mathrm{H}\right] \mathrm{EG}$ for OATP1B3. The typical inhibitors were used as follows: TEA (0-50 mM) for OCT1 and OCT2, probenecid $(0-250 \mu \mathrm{M})$ for OAT1 and OAT3, and rifampin $(0-250 \mu \mathrm{M})$ for OATP1B1 and OATP1B3. The concentrations of the ginsenosides Rb1, Rb2, Rc, Rd, compound K, Rg3, Rh2, PPD, PPT, Re, Rg1, and Rh1 ranged from $0.1 \mu \mathrm{M}$ to $100 \mu \mathrm{M}$. Then the uptake of probe substrates into HEK293-mock cells and HEK293-OCT1, -OCT2, -OAT1, -OAT3, -OATP1B1, and -OATP1B3 cells in the presence and absence of typical inhibitor or each ginsenoside with previously described concentration range was measured for $5 \mathrm{~min}$. Immediately after placing the plates on ice, the cells were washed three times with $100 \mu \mathrm{L}$ of ice-cold HBSS, followed by lysing with $50 \mu \mathrm{L}$ of $10 \%$ SDS solution and mixing with $150 \mu \mathrm{L}$ of Optiphase cocktail solution (Perkin Elmer Inc., Boston, MA, USA). The radioactivity of the probe substrates in the cells was determined using a liquid scintillation counter.

The uptake of valsartan $5(\mu \mathrm{M})$ was measured for 5 min immediately after adding aliquots $(100 \mu \mathrm{L})$ of HBSS containing $5 \mu \mathrm{M}$ valsartan in the presence or absence of rifampin $(1-100 \mu \mathrm{M})$ or tri-glycosylated PPD-type ginsenosides (Rb1, Rb2, and Rc; 0.1-100 $\mu \mathrm{M}$ ) to the HEK293-mock cells and HEK293-OATP1B1 and-OAPT1B3 cells after aspirating pre-incubated HBSS. After 5 min incubation, the cells were washed three times with $100 \mu \mathrm{L}$ of ice-cold HBSS, followed by lysing with $300 \mu \mathrm{L}$ of $80 \%$ ice-cold methanol containing berberine $0.05 \mathrm{ng} / \mathrm{mL}$ and $0.1 \%$ formic acid for $15 \mathrm{~min}$. After the centrifugation of cell lysate samples $\left(16,000 \times g, 5 \mathrm{~min}, 4^{\circ} \mathrm{C}\right)$, aliquots $(4 \mu \mathrm{L})$ of cell lysate samples were injected into LC-MS/MS system for the analysis of valsartan. Transporter mediated uptake of probe substrates or valsartan was calculated by subtracting the uptake rate of probe substrates or valsartan into HEK293-mock cells from that into HEK293 cells expressing respective transporters. 


\subsection{Animals and Ethical Approval}

Male Sprague-Dawley rats (6-7-weeks old, 220-250 g) were purchased from Samtako Co. (Osan, Korea). The animals were acclimatized for 1 week in an animal facility at Kyungpook National University. Food and water were provided ad libitum. All animal procedures were approved by the Animal Care and Use Committee of Kyungpook National University (Approval No. KNU 2017-21 and KNU 2019-83). To calculate and compare the pharmacokinetic parameters of valsartan and ginsenosides, we performed repeated blood sampling through the retro-orbital puncture under isoflurane anesthesia. During the experimental procedure, rats did not suffer from any significant injury or infection.

\subsection{Pharmacokinetic Study}

The rats were randomly divided into the control and rifampin groups. The rifampin group was orally administered with rifampin solution $(20 \mathrm{mg} / 2 \mathrm{~mL} / \mathrm{kg}$, dissolved in DMSO: saline $=2: 8, v / v)$ and the control group received only the vehicle via oral gavage. Valsartan was injected intravenously to both groups via the tail vein at $1 \mathrm{mg} / \mathrm{mL} / \mathrm{kg}$ (dissolved in DMSO: saline $=2: 8, v / v$ ). Blood samples were collected via the retro-orbital vein at $0.25,0.5,1,2,4,8$, and $24 \mathrm{~h}$ following valsartan dosing. After the centrifugation of blood samples $\left(16,000 \times g, 10 \mathrm{~min}, 4{ }^{\circ} \mathrm{C}\right)$, aliquots $(50 \mu \mathrm{L}$ each) of plasma samples were stored at $-80^{\circ} \mathrm{C}$ until the analysis of valsartan.

The rats were randomly divided into the control and RGE groups. The RGE group received a RGE suspension $(1.5 \mathrm{~g} / \mathrm{mL} / \mathrm{kg} /$ day, in distilled water) for 7 days via oral gavage. The control group received distilled water for 7 days via oral gavage. After $1 \mathrm{~h}$ following the last RGE treatment, valsartan was injected intravenously to both groups via the tail vein at $1 \mathrm{mg} / \mathrm{mL} / \mathrm{kg}$ (dissolved in DMSO: saline = 2:8, $v / v$ ). Blood samples were collected via the retro-orbital vein at $0.25,0.5,1,2,4,8,24,30$, and $48 \mathrm{~h}$ after valsartan dosing. After centrifugation of the blood samples at $16,000 \times g$ for $10 \mathrm{~min}$, aliquots $(50 \mu \mathrm{L}$ each) of plasma samples were stored at $-80^{\circ} \mathrm{C}$ until the analysis of ginsenosides and valsartan.

The rats were randomly divided into the control and Rc groups. The Rc group was injected with Rc solution ( $3 \mathrm{mg} / \mathrm{mL} / \mathrm{kg}$, dissolved in saline) intravenously via the tail vein for 5 consecutive days. The control group received saline $(1 \mathrm{~mL} / \mathrm{kg})$ for 5 consecutive days via the tail vein. After $1 \mathrm{~h}$ following the last Rc treatment, valsartan was injected intravenously via the femoral vein at $1 \mathrm{mg} / \mathrm{kg}$. Blood samples were collected via the retro-orbital vein at $0.17,0.33,0.67,1.5,2,4,8,24$, and $48 \mathrm{~h}$ after valsartan dosing. After centrifugation of the blood samples $\left(16,000 \times g, 10 \mathrm{~min}, 4{ }^{\circ} \mathrm{C}\right)$, aliquots $(50 \mu \mathrm{L}$ each) of plasma samples were stored at $-80^{\circ} \mathrm{C}$ until the analysis of the ginsenoside Rc and valsartan.

The rats were injected with Rc solution $(3 \mathrm{mg} / \mathrm{mL} / \mathrm{kg}$, dissolved in saline) via the tail vein. Blood samples were collected from the abdominal artery, and the liver tissue was immediately excised, gently washed with ice-cold saline, and weighed after the rats were euthanized at 2,12, and $48 \mathrm{~h}$ after intravenous injection of Rc. The blood samples were centrifuged $\left(16,000 \times g, 10 \mathrm{~min}, 4{ }^{\circ} \mathrm{C}\right)$ and the liver tissue samples were homogenized with four volumes of saline. Aliquots (50 $\mu \mathrm{L}$ each) of plasma and liver homogenates were stored at $-80^{\circ} \mathrm{C}$ until the analysis of the ginsenoside Rc.

The protein binding of $\mathrm{Rb} 1, \mathrm{Rb} 2$, and $\mathrm{Rc}(1 \mu \mathrm{M})$ in rat plasma and liver homogenate was determined using a rapid equilibrium dialysis kit (ThermoFisher Scientific Korea, Seoul, Korea) according to the manufacturer's instructions. Briefly, $100 \mu \mathrm{L}$ of rat plasma and $10 \%$ liver homogenate samples containing $\mathrm{Rb} 1, \mathrm{Rb} 2$, or $\mathrm{Rc}(1 \mu \mathrm{M})$ were added to the sample chamber of a semipermeable membrane (molecular weight cut-off $8000 \mathrm{Da}$ ) and $300 \mu \mathrm{L}$ of HBSS was added to the outer buffer chamber. Four hours after incubation at $37^{\circ} \mathrm{C}$ on a shaking incubator at $300 \mathrm{rpm}$, aliquots $(50 \mu \mathrm{L})$ were collected from both the sample and buffer chambers and treated with equal volumes of fresh HBSS and plasma, respectively, to match the sample matrices. The matrix-matched samples $(100 \mu \mathrm{L})$ were mixed with $300 \mu \mathrm{L}$ of $80 \%$ ice-cold methanol containing berberine $0.05 \mathrm{ng} / \mathrm{mL}$ and $0.1 \%$ formic acid for $15 \mathrm{~min}$. After centrifugation $\left(16,100 \times g, 5 \mathrm{~min}, 4^{\circ} \mathrm{C}\right)$, an aliquot $(4 \mu \mathrm{L})$ from the sample was injected into LC-MS/MS system. 
Plasma protein binding was calculated using the following equation [47].

$$
\text { Undiluted free drug fraction }(\mathbf{f u})=\frac{\text { Drug concentration in buffer chamber }}{\text { Drug concentration in plasma chamber }}
$$

Tissue protein binding was calculated using the following equations, and a dilution factor ( $\mathrm{D}$ as a value of 10) was used since we used $10 \%$ liver homognenates $[47,48]$.

$$
\begin{aligned}
& \text { Diluted free drug fraction }\left(\mathrm{fu}^{\prime}\right)=\frac{\text { Drug concentration in buffer chamber }}{\text { Drug concentration in liver homogenate chamber }} \\
& \text { Undiluted free drug fraction }(\mathrm{fu})=\frac{1 / \mathrm{D}}{\left(\frac{1}{\mathrm{fu}^{\prime}}-1\right)+1 / \mathrm{D}}=\frac{0.1}{\left(\frac{1}{\mathrm{fu}^{\prime}}-1\right)+0.1}
\end{aligned}
$$

\subsection{LC-MS/MS Analysis of Valsartan}

The concentration of valsartan was analyzed using a modified Liquid chromatography-mass spectrometry (LC-MS/MS) method as previously reported by Yamashiro et al. [29] using an Agilent 6470 Triple Quad LC-MS/MS system (Agilent, Wilmington, DE, USA).

Briefly, aliquots $(50 \mu \mathrm{L})$ of plasma samples were mixed with $350 \mu \mathrm{L}$ of an internal standard (IS) solution (berberine $0.05 \mathrm{ng} / \mathrm{mL}$ in methanol) and the mixtures were vortexed for $15 \mathrm{~min}$. After centrifugation $\left(16,100 \times g, 5 \mathrm{~min}, 4^{\circ} \mathrm{C}\right), 100 \mu \mathrm{L}$ of the supernatant was transferred to a clean tube, evaporated and an aliquot $(4 \mu \mathrm{L})$ from the sample was injected into LC-MS/MS system.

The samples were eluted through a Synergy Polar RP column $(2.0 \mathrm{~mm} \times 150 \mathrm{~mm}, 4 \mu \mathrm{m}$ particle size) (Phenomenex, Torrance, CA, USA) using a mobile phase consisting of methanol and water (75:25, $v / v$ ) with $0.1 \%$ formic acid at a flow rate of $0.2 \mathrm{~mL} / \mathrm{min}$. Valsartan and berberine (IS) were detected at a retention time $\left(\mathrm{T}_{\mathrm{R}}\right)$ of $2.6 \mathrm{~min}$ and $3.5 \mathrm{~min}$, respectively, by electrospray ionization in the positive ion mode. Quantification was performed in the selected reaction-monitoring mode at $m / z 436.1 \rightarrow 291.0$ for valsartan and $\mathrm{m} / \mathrm{z} 336.1 \rightarrow 320.0$ for berberine. Plasma calibration standards for the measurement of valsartan ranged from $1 \mathrm{ng} / \mathrm{mL}$ to $2000 \mathrm{ng} / \mathrm{mL}$, and the intraday and interday accuracy ranged from $93.35 \%$ to $99.63 \%$. The intraday and interday precision ranged from $1.80 \%$ to $9.23 \%$.

\subsection{LC-MS/MS analysis of Ginsenosides}

The concentration of compound $\mathrm{K}$ was analyzed using a modified LC-MS/MS method of Jin et al. [31] using an Agilent 6470 Triple Quad LC-MS/MS system (Agilent, Wilmington, DE, USA).

For the detection of $\mathrm{Rb} 1, \mathrm{Rb} 2, \mathrm{Rc}, \mathrm{Rd}, \mathrm{Re}, \mathrm{Rg} 1, \mathrm{Rh} 2$, and $\mathrm{Rg} 3$, aliquots $(50 \mu \mathrm{L})$ of plasma and liver homogenates were mixed with $350 \mu \mathrm{L}$ of IS solution $(0.05 \mathrm{ng} / \mathrm{mL}$ berberine in methanol) and vortexed for $15 \mathrm{~min}$. After centrifugation $\left(16,100 \times \mathrm{g}\right.$ for $\left.5 \mathrm{~min}, 4^{\circ} \mathrm{C}\right), 200 \mu \mathrm{L}$ of the supernatant was transferred to a clean tube and evaporated. The residue was reconstituted with $100 \mu \mathrm{L}$ of $70 \%$ methanol consisting of $0.1 \%$ formic acid. An aliquot $(20 \mu \mathrm{L})$ from the sample was injected into the LC-MS/MS system. The samples were eluted through a Synergy Polar RP column $(2.0 \mathrm{~mm} \times 150 \mathrm{~mm}, 4 \mu \mathrm{m}$ particle size) (Phenomenex, Torrance, CA, USA) with a gradient mobile phase consisting of $0.1 \%$ formic acid in water (phase A) and $0.1 \%$ formic acid in methanol (phase B) as follows: $69 \%$ of phase B for 0-2.0 $\mathrm{min}, 69-85 \%$ of phase B for $2.0-4.0 \mathrm{~min}$, and $85-69 \%$ of phase B for $6.0-6.5 \mathrm{~min}$ at a flow rate of $0.27 \mathrm{~mL} / \mathrm{min}$. The ginsenosides $\mathrm{Rb} 1, \mathrm{Rb} 2, \mathrm{Rc}, \mathrm{Rd}, \mathrm{Re}, \mathrm{Rg} 1, \mathrm{Rh} 2, \mathrm{Rg} 3$, and berberine (IS) were detected at $m / z 1131.6 \rightarrow 365.1$ (for $\mathrm{Rb} 1, \mathrm{~T}_{\mathrm{R}} 4.6 \mathrm{~min}$ ), $\mathrm{m} / \mathrm{z} 1101.6 \rightarrow 335.1$ (for $\mathrm{Rb} 2$ and $\mathrm{Rc}, \mathrm{T}_{\mathrm{R}} 5.7 \mathrm{~min}$ and $4.8 \mathrm{~min}$, respectively), $\mathrm{m} / \mathrm{z} 969.9 \rightarrow 789.5$ (for $\mathrm{Rd}$ and $\mathrm{Re}, \mathrm{T}_{\mathrm{R}} 6.8 \mathrm{~min}$ and $2.1 \mathrm{~min}$, respectively), $\mathrm{m} / \mathrm{z} 824.0 \rightarrow$ 643.6 (for Rg1, $\mathrm{T}_{\mathrm{R}} 2.2 \mathrm{~min}$ ), $\mathrm{m} / \mathrm{z} 587.4 \rightarrow 4.7 .4$ (for $\mathrm{Rh} 2, \mathrm{~T}_{\mathrm{R}} 10.7 \mathrm{~min}$ ), $\mathrm{m} / \mathrm{z} 807.5 \rightarrow 365.1$ (for $\mathrm{Rg} 3, \mathrm{~T}_{\mathrm{R}}$ $9.3 \mathrm{~min}$ ), and $\mathrm{m} / \mathrm{z} 336.1 \rightarrow 320.0$ (for berberine, $\mathrm{T}_{\mathrm{R}} 4.5 \mathrm{~min}$ ) in the positive ion mode.

For the detection of Rh1, compound K, PPD, and PPT, aliquots $(50 \mu \mathrm{L})$ of plasma and liver homogenates were mixed with $50 \mu \mathrm{L}$ of IS solution ( $25 \mathrm{ng} / \mathrm{mL}$ caffeine in water) and $600 \mu \mathrm{L}$ of methyl 
tertiary-butyl ether (MTBE), vortexed for $15 \mathrm{~min}$, and centrifuged at 16,100× $\mathrm{g}$ for $5 \mathrm{~min}$. After freezing the aqueous layer at $-80{ }^{\circ} \mathrm{C}$ for $2 \mathrm{~h}$, the upper organic layer was transferred to a clean tube and evaporated to dryness. The residue was reconstituted with $150 \mu \mathrm{L}$ of $85 \%$ methanol. An aliquot $(20 \mu \mathrm{L})$ from the sample was injected into the LC-MS/MS system. The samples were eluted through an Omega Polar C18 column ( $2.1 \mathrm{~mm} \times 100 \mathrm{~mm}, 3 \mu \mathrm{m}$ particle size) (Phenomenex, Torrance, CA, USA) using a mobile phase consisting of $0.1 \%$ formic acid in water: $0.1 \%$ formic acid in methanol $(15: 85, v / v)$ at a flow rate of $0.2 \mathrm{~mL} / \mathrm{min}$. The ginsenosides Rh1, Rh2, compound K, PPD, PPT, and caffeine (IS) were detected at $m / z 603.4 \rightarrow 423.4$ (for Rh1, $\mathrm{T}_{\mathrm{R}} 2.7 \mathrm{~min}$ ), $\mathrm{m} / \mathrm{z} 645.5 \rightarrow 203.1$ (for compound $\mathrm{K}, \mathrm{T}_{\mathrm{R}} 5.3 \mathrm{~min}$ ), $\mathrm{m} / \mathrm{z} 425.3 \rightarrow 109.1$ (for PPD, $\mathrm{T}_{\mathrm{R}} 7.7 \mathrm{~min}$ ), $\mathrm{m} / \mathrm{z} 441.3 \rightarrow 109.1$ (for PPT, $\mathrm{T}_{\mathrm{R}} 3.5 \mathrm{~min}$ ), and $\mathrm{m} / \mathrm{z} 195 \rightarrow 138$ (for caffeine, $\mathrm{T}_{\mathrm{R}} 3.6 \mathrm{~min}$ ) in the positive ion mode. The calibration standards for the measurement of 12 ginsenosides ranged from $0.5 \mathrm{ng} / \mathrm{mL}$ to $200 \mathrm{ng} / \mathrm{mL}$, and the coefficient of variance for intraday and interday accuracy and precision were less than $15 \%$.

\subsection{Data Analysis}

In the inhibition studies, the uptake rate of substrate by HEK293 cells overexpressing the respective transporters was used as the control $(100 \%)$ and the uptake rate of substrates in the presence of typical inhibitors or ginsenosides expressed as a percentage of the control. The inhibition data were fitted to an inhibitory effect model [26] using Sigma plot (version 10.0; Systat Software Inc., San Jose, CA, USA). $\mathrm{IC}_{50}$ value indicated the half-maximal inhibitory concentration of the inhibitor.

Pharmacokinetic parameters were calculated from plasma concentration-time profile using non-compartment analysis of WinNonlin (version 5.1; Pharsights, Cary, NC, USA). The statistical significance was assessed by t-test using Statistical Package for the Social Sciences (version 24.0; SPSS Inc., Chicago, IL, USA).

Author Contributions: Conceptualization: I.-S.S.; methodology, J.-H.J, S.J., and M.-K.C.; validation, J.-H.J, S.J., and M.-K.C.; formal analysis, W.L.; investigation, J.-H.J, S.L., W.L., S.J., M.K., C.H.S., and I.-S.S.; writing—original draft preparation, J.-H.J. and I.-S.S.; writing-review and editing, M.-K.C. and I.-S.S.; supervision, I.-S.S.; project administration, I.-S.S.; funding acquisition, I.-S.S. All authors have read and agreed to the published version of the manuscript.

Funding: This research was supported by Kyungpook National University Development Project Research Fund, 2018.

Conflicts of Interest: The authors declare no conflict of interest.

\section{References}

1. Ru, W.; Wang, D.; Xu, Y.; He, X.; Sun, Y.E.; Qian, L.; Zhou, X.; Qin, Y. Chemical constituents and bioactivities of Panax ginseng (C. A. Mey.). Drug Discov. Ther. 2015, 9, 23-32. [CrossRef]

2. Lee, C.H.; Kim, J.H. A review on the medicinal potentials of ginseng and ginsenosides on cardiovascular diseases. J. Ginseng Res. 2014, 38, 161-166. [CrossRef] [PubMed]

3. Choi, K.T. Botanical characteristics, pharmacological effects and medicinal components of Korean Panax ginseng C A Meyer. Acta Pharmacol. Sin. 2008, 29, 1109-1118. [CrossRef] [PubMed]

4. Kim, J.H.; Yi, Y.S.; Kim, M.Y.; Cho, J.Y. Role of ginsenosides, the main active components of Panax ginseng, in inflammatory responses and diseases. J. Ginseng Res. 2017, 41, 435-443. [CrossRef] [PubMed]

5. Yun, T.K.; Choi, S.Y.; Yun, H.Y. Epidemiological study on cancer prevention by ginseng: Are all kinds of cancers preventable by ginseng? J. Korean Med. Sci. 2001, 16, 19-27. [CrossRef] [PubMed]

6. Gui, Q.F.; Xu, Z.R.; Xu, K.Y.; Yang, Y.M. The efficacy of ginseng-related therapies in type 2 diabetes mellitus: An updated systematic review and meta-analysis. Medicine 2016, 95, e2584. [CrossRef] [PubMed]

7. Park, T.Y.; Hong, M.; Sung, H.; Kim, S.; Suk, K.T. Effect of Korean Red Ginseng in chronic liver disease. J. Ginseng Res. 2017, 41, 450-455. [CrossRef]

8. Lee, S.; Kwon, M.; Choi, M.K.; Song, I.S. Effects of red ginseng extract on the pharmacokinetics and elimination of methotrexate via Mrp2 regulation. Molecules 2018, 23, 2948. [CrossRef]

9. Lu, J.M.; Yao, Q.; Chen, C. Ginseng compounds: An update on their molecular mechanisms and medical applications. Curr. Vasc. Pharmacol. 2009, 7, 293-302. [CrossRef] 
10. Wu, X.; Ma, J.; Ye, Y.; Lin, G. Transporter modulation by Chinese herbal medicines and its mediated pharmacokinetic herb-drug interactions. J. Chromatogr. B Analyt. Technol. Biomed. Life Sci. 2016, 1026, 236-253. [CrossRef]

11. Na, D.H.; Ji, H.Y.; Park, E.J.; Kim, M.S.; Liu, K.H.; Lee, H.S. Evaluation of metabolism-mediated herb-drug interactions. Arch. Pharm. Res. 2011, 34, 1829-1842. [CrossRef] [PubMed]

12. Jo, J.J.; Lee, S. Investigation of herb-drug interactions between Korean red ginseng extract and five Cyp substrates by LC-MS/MS. Mass Spectrom. Lett. 2017, 8, 98-104.

13. Kim, H.; Nam, W.; Kim, S.H.; Jang, H.R.; Lee, M.K.; Kim, T.W.; Lee, S. Modulatory effects of Korean red ginseng extract (Panax ginseng C.A. Meyer) on cytochrome P450 after oral administration to mice for 14 days. J. Life Sci. 2012, 22, 991-998. [CrossRef]

14. Seong, S.J.; Kang, W.Y.; Heo, J.K.; Jo, J.; Choi, W.G.; Liu, K.H.; Lee, S.; Choi, M.K.; Han, Y.H.; Lee, H.S.; et al. A comprehensive in vivo and in vitro assessment of the drug interaction potential of red ginseng. Clin. Ther. 2018, 40, 1322-1337. [CrossRef] [PubMed]

15. Kim, D.S.; Kim, Y.; Jeon, J.Y.; Kim, M.G. Effect of Red Ginseng on cytochrome P450 and P-glycoprotein activities in healthy volunteers. J. Ginseng Res. 2016, 40, 375-381. [CrossRef]

16. Malati, C.Y.; Robertson, S.M.; Hunt, J.D.; Chairez, C.; Alfaro, R.M.; Kovacs, J.A.; Penzak, S.R. Influence of Panax ginseng on cytochrome P450 (CYP)3A and P-glycoprotein (P-gp) activity in healthy participants. J. Clin. Pharmacol. 2012, 52, 932-939. [CrossRef]

17. Kim, S.J.; Choi, S.; Kim, M.; Park, C.; Kim, G.L.; Lee, S.O.; Kang, W.; Rhee, D.K. Effect of Korean Red Ginseng extracts on drug-drug interactions. J. Ginseng Res. 2018, 42, 370-378. [CrossRef]

18. Zhang, R.; Jie, J.; Zhou, Y.; Cao, Z.; Li, W. Long-term effects of Panax ginseng on disposition of fexofenadine in rats in vivo. Am. J. Chin. Med. 2009, 37, 657-667. [CrossRef]

19. Jin, S.; Lee, S.; Jeon, J.H.; Kim, H.; Choi, M.K.; Song, I.S. Enhanced intestinal permeability and plasma concentration of metformin in rats by the repeated administration of red ginseng extract. Pharmaceutics 2019, 11, 189. [CrossRef]

20. Choi, M.K.; Song, I.S. Interactions of ginseng with therapeutic drugs. Arch. Pharm Res. 2019, 42, 862-878. [CrossRef]

21. Lee, H.; Heo, J.-K.; Lee, G.-H.; Park, S.-Y.; Jang, S.N.; Kim, H.-J.; Kwon, M.J.; Song, I.-S.; Liu, K.-H. Ginsenoside Rc is a new selective UGT1A9 inhibitor in human liver microsomes and recombinant human UGT isoforms. Drug Metab. Dispos. 2019, 47, 1372-1379. [CrossRef] [PubMed]

22. Kim, D.; Zheng, Y.F.; Min, J.S.; Park, J.B.; Bae, S.H.; Yoon, K.D.; Chin, Y.W.; Oh, E.; Bae, S.K. In vitro stereoselective inhibition of ginsenosides toward UDP-glucuronosyltransferase (UGT) isoforms. Toxicol. Lett. 2016, 259, 1-10. [CrossRef] [PubMed]

23. Jiang, R.; Dong, J.; Li, X.; Du, F.; Jia, W.; Xu, F.; Wang, F.; Yang, J.; Niu, W.; Li, C. Molecular mechanisms governing different pharmacokinetics of ginsenosides and potential for ginsenoside-perpetrated herb-drug interactions on OATP1B3. Br. J. Pharmacol. 2015, 172, 1059-1073. [CrossRef] [PubMed]

24. Lee, W.-K.; Reichold, M.; Edemir, B.; Ciarimboli, G.; Warth, R.; Koepsell, H.; Thévenod, F. Organic cation transporters OCT1, 2, and 3 mediate high-affinity transport of the mutagenic vital dye ethidium in the kidney proximal tubule. Am. J. Physiol. Physiol. 2009, 296, F1504-F1513. [CrossRef] [PubMed]

25. Choi, M.K.; Jin, Q.R.; Jin, H.E.; Shim, C.K.; Cho, D.Y.; Shin, J.G.; Song, I.S. Effects of tetraalkylammonium compounds with different affinities for organic cation transporters on the pharmacokinetics of metformin. Biopharm. Drug Dispos. 2007, 28, 501-510. [CrossRef]

26. Kim, S.; Choi, W.-G.; Kwon, M.; Lee, S.; Cho, Y.-Y.; Lee, J.Y.; Kang, H.C.; Song, I.-S.; Lee, H.S. In Vitro Inhibitory Effects of APINACA on Human Major Cytochrome P450, UDP-Glucuronosyltransferase Enzymes, and Drug Transporters. Molecules 2019, 24, 3000. [CrossRef] [PubMed]

27. Parvez, M.M.; Jung, J.A.; Shin, H.J.; Kim, D.H.; Shin, J.G. Characterization of 22 Antituberculosis Drugs for Inhibitory Interaction Potential on Organic Anionic Transporter Polypeptide (OATP)-Mediated Uptake. Antimicrob. Agents Chemother. 2016, 60, 3096-3105. [CrossRef] [PubMed]

28. Kalliokoski, A.; Niemi, M. Impact of OATP transporters on pharmacokinetics. Br. J. Pharmacol. 2009, 158, 693-705. [CrossRef]

29. Yamashiro, W.; Maeda, K.; Hirouchi, M.; Adachi, Y.; Hu, Z.; Sugiyama, Y. Involvement of transporters in the hepatic uptake and biliary excretion of valsartan, a selective antagonist of the angiotensin II AT1-receptor, in humans. Drug Metab. Dispos. 2006, 34, 1247-1254. [CrossRef] 
30. Poirier, A.; Cascais, A.C.; Funk, C.; Lave, T. Prediction of pharmacokinetic profile of valsartan in human based on in vitro uptake transport data. J. Pharmacokinet. Pharmacodyn. 2009, 36, 585-611. [CrossRef]

31. Jin, S.; Jeon, J.H.; Lee, S.; Kang, W.Y.; Seong, S.J.; Yoon, Y.R.; Choi, M.K.; Song, I.S. Detection of 13 ginsenosides (Rb1, Rb2, Rc, Rd, Re, Rf, Rg1, Rg3, Rh2, F1, Compound K, 20(S)-Protopanaxadiol, and 20(S)-Protopanaxatriol) in human plasma and application of the analytical method to human pharmacokinetic studies following two week-repeated administration of red ginseng extract. Molecules 2019, 24, 2618.

32. Dong, W.W.; Zhao, J.; Zhong, F.L.; Zhu, W.J.; Jiang, J.; Wu, S.; Yang, D.C.; Li, D.; Quan, L.H. Biotransformation of Panax ginseng extract by rat intestinal microflora: Identification and quantification of metabolites using liquid chromatography-tandem mass spectrometry. J. Ginseng Res. 2017, 41, 540-547. [CrossRef] [PubMed]

33. Choi, M.K.; Jin, S.; Jeon, J.H.; Kang, W.Y.; Seong, S.J.; Yoon, Y.R.; Han, Y.H.; Song, I.S. Tolerability and pharmacokinetics of ginsenosides $\mathrm{Rb} 1, \mathrm{Rb} 2, \mathrm{Rc}, \mathrm{Rd}$, and compound $\mathrm{K}$ after single or multiple administration of red ginseng extract in human beings. J. Ginseng Res. 2018. [CrossRef]

34. Shitara, Y.; Maeda, K.; Ikejiri, K.; Yoshida, K.; Horie, T.; Sugiyama, Y. Clinical significance of organic anion transporting polypeptides (OATPs) in drug disposition: Their roles in hepatic clearance and intestinal absorption. Biopharm. Drug Dispos. 2013, 34, 45-78. [CrossRef] [PubMed]

35. Zha, W. Transporter-mediated natural product-drug interactions for the treatment of cardiovascular diseases. J. Food Drug Anal. 2018, 26, S32-S44. [CrossRef] [PubMed]

36. Nam, S.J.; Han, Y.J.; Lee, W.; Kang, B.; Choi, M.K.; Han, Y.H.; Song, I.S. Effect of red ginseng extract on the pharmacokinetics and efficacy of metformin in streptozotocin-induced diabetic rats. Pharmaceutics 2018, 10, 80. [CrossRef]

37. Hong, B.N.; Ji, M.G.; Kang, T.H. The efficacy of red ginseng in type 1 and type 2 diabetes in animals. Evid Based Complement. Alternat Med. 2013, 2013, 593181. [CrossRef]

38. Yuan, H.D.; Kim, J.T.; Kim, S.H.; Chung, S.H. Ginseng and diabetes: The evidences from in vitro, animal and human studies. J. Ginseng Res. 2012, 36, 27-39. [CrossRef]

39. Ma, L.; Wei, Y.; Zhou, Y.; Ma, X.; Wu, X. Effects of Pluronic F68 and Labrasol on the intestinal absorption and pharmacokinetics of rifampicin in rats. Arch. Pharm Res. 2011, 34, 1939-1943. [CrossRef]

40. Shimomura, H.; Nogami, R.; Shigeno, A.; Shimada, S.; Aoyama, T. Influence of Food on Rifampicin Pharmacokinetics in Rats. Biol Pharm. Bull. 2016, 39, 49-53. [CrossRef]

41. Mucalo, I.; Jovanovski, E.; Vuksan, V.; Bozikov, V.; Romic, Z.; Rahelic, D. American ginseng extract (Panax quinquefolius L.) Is safe in long-term use in type 2 diabetic patients. Evid Based Complement. Alternat Med. 2014, 2014, 969168. [CrossRef] [PubMed]

42. Laube, R.; Liu, K. An unwanted complement: Rare case of potential liver injury induced by an interaction between ginseng and atorvastatin. Br. J. Clin. Pharmacol. 2019, 85, 1612-1613. [CrossRef] [PubMed]

43. Chu, Y.; Zhang, H.C.; Li, S.M.; Wang, J.M.; Wang, X.Y.; Li, W.; Zhang, L.L.; Ma, X.H.; Zhou, S.P.; Zhu, Y.H.; et al. Determination of ginsenoside Rc in rat plasma by LC-MS/MS and its application to a pharmacokinetic study. J. Chromatogr. B Analyt. Technol. Biomed. Life Sci. 2013, 919-920, 75-78. [CrossRef] [PubMed]

44. Lee, M.S.; Hwang, J.T.; Kim, S.H.; Yoon, S.; Kim, M.S.; Yang, H.J.; Kwon, D.Y. Ginsenoside Rc, an active component of Panax ginseng, stimulates glucose uptake in C2C12 myotubes through an AMPK-dependent mechanism. J. Ethnopharmacol. 2010, 127, 771-776. [CrossRef]

45. Jeong, H.U.; Kang, H.E.; Choi, S.Z.; Son, M.; Song, I.S.; Lee, H.S. Evaluation of drug-drug interaction potential between DA-9801 and metformin. J. Pharm. Investig. 2014, 44, 401-409. [CrossRef]

46. Jeong, H.U.; Kwon, M.; Lee, Y.; Yoo, J.S.; Shin, D.H.; Song, I.S.; Lee, H.S. Organic anion transporter 3and organic anion transporting polypeptides 1B1- and 1B3-mediated transport of catalposide. Drug Des. Devel. Ther. 2015, 9, 643-653. 
47. Schuhmacher, J.; Bühner, K.; Witt-Laido, A. Determination of the free fraction and relative free fraction of drugs strongly bound to plasma proteins. J. Pharm. Sci. 2000, 89, 1008-1021. [CrossRef]

48. Kalvass, J.C.; Maurer, T.S. Influence of nonspecific brain and plasma binding on CNS exposure: implications for rational drug discovery. Biopharm. Drug Dispos. 2002, 23, 327-338. [CrossRef]

Sample Availability: Not available.

(C) 2020 by the authors. Licensee MDPI, Basel, Switzerland. This article is an open access article distributed under the terms and conditions of the Creative Commons Attribution (CC BY) license (http://creativecommons.org/licenses/by/4.0/). 